\title{
UNIVERSITY OF MICHIGAN RADIOCARBON DATES XII
}

\author{
H. R. CRANE and JAMES B. GRIFFIN
}

The University of Michigan, Ann Arbor, Michigan

The following is a list of dates obtained since the compilation of List XI in December 1965. The method is essentially the same as described in that list. Two $\mathrm{CO}_{2}-\mathrm{CS}_{2}$ Geiger counter systems were used. Equipment and counting techniques have been described elsewhere (Crane, 1961). Dates and estimates of error in this list follow the practice recommended by the International Radiocarbon Dating Conferences of 1962 and 1965, in that (a) dates are computed on the basis of the Libby half-life, $5570 \mathrm{yr}$, (b) A.D. 1950 is used as the zero of the age scale, and (c) the errors quoted are the standard deviations obtained from the numbers of counts only. In previous Michigan date lists up to and including VII, we have quoted errors at least twice as great as the statistical errors of counting, to take account of other errors in the over-all process. If the reader wishes to obtain a standard deviation figure which will allow ample room for the many sources of error in the dating process, we suggest doubling the figures that are given in this list.

We wish to acknowledge the help of Patricia Dahlstrom in preparing chemical samples and David M. Griffin and Linda B. Halsey in preparing the descriptions.

I. GEOLOGIC SAMPLFS

\section{M-1291. Hosterman's Pit, Pennsylvania \\ $9240 \pm 1000$}

Charcoal from Hosterman's Pit $\left(40^{\circ} 53^{\prime} 34^{\prime \prime} \mathrm{N}\right.$ Lat, $77^{\circ} 26^{\prime} 22^{\prime \prime} \mathrm{W}$ Long), Centre Co., Pennsylvania. Sample found in cave mixed in rocky talus with assorted mammal bones, including elk (Cervus canadensis), that apparently fell in at a former entrance. Species are characteristic of area today except elk, which was exterminated ca. 1860 to 1870. Flowstone had formed over several bones. Coll. 1961 by A.D. McCrady; subm. by J. E. Guilday, Carnegie Mus., Pittsburgh, Pa. Comment (JEG): earliest $\mathrm{C}^{14}$ (late yet run on an assemblage of Recent vertebrates in NE U.S.

\section{0 в.с.}

Bison bone from Waldron Ranch bone locality $\left(49^{\circ} 45^{\prime} 30^{\prime \prime} \mathrm{N}\right.$ Lat, $114^{\circ} 05^{\prime} 30^{\prime \prime} \mathrm{W}$ Long), Alberta, Canada. Sample from bone bed (Wagner, 1966) in east bank of (lry coulee $1 / 2 \mathrm{mi}$. above junction of Callum Creek and Oldman River, 30 yds upstream from Callum Creek. Coll. 1964 by K. E. Campbell and W. P. Wagner; subm. by W. P. Wagner, Univ. of Vermont. Comment (WPW): date is youngest known age for alluvial unit; younger than Mount Mazama ash. 


\section{M-1736. Lake Chippewa Low Stage, Michigan}

Shell from Lake Chippewa Low Stage $\left(43^{\circ} 08.4^{\prime} \mathrm{N}\right.$ Lat, $86^{\circ} 48.7^{\prime} \mathrm{W}$ Long), Michigan. Sample consisted of shallow water pelecypod (and other species) from layer of shells and sand believed to represent Lake Chippewa Low Water Stage of Lake Michigan. Taken from depth of 315 ft. Previous date obtained on smaller weight of shells from another similar locality at $395 \mathrm{ft}$. was $7400 \pm 500$ B.P. (M-1571, Michigan X) the right order of magnitude for event. Coll. 1964 and subm. by J. L. Hough, Great Lakes Research Division, Univ. of Michigan. Comment (JLH): date is in reasonable conformity with sample at slightly lower lake level.

\section{M-1739. Gratiot County Mastodon, Michigan $\quad 9910 \pm 350$ Thaller Mastodon \\ 7960 B.C.}

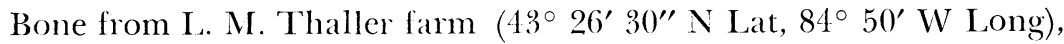
SE $1 / 4$ NE 1/4 NE 1/4 Sec. 18, Serville Twp., Gratiot Co., Michigan. Parts of hind leg, ulna, and tusk found by drag-line operator. Coll. 1965 by H. P. Mouller; subm. by C. W. Hibbard, Univ. of Michigan. Comment (CWH): as will be noted from dates at Rappuhn Mastodon site, $\mathrm{C}^{1+}$ date on bone may be significantly younger than associated wood or peat. This suggests age of Thaller Mastodon may be closer to 11,000 B.P. than 10,000 B.P. Pollen study on this location will be published by R. O. Kapp, Alma College, Mich., and on the diatoms by Matt Holm of Central Mich. Univ. Comment (ROK): pollen from sediments of peat and clay, in which bones were deposited, belongs to late-glacial spruce pollen zone, so that clate is slightly younger than expected.

\section{Thaller Mastodon series, Michigan}

Wood, peat, and gyttja from Louis Thaller farm $\left(43^{\circ} 26^{\prime} 30^{\prime \prime} \mathrm{N}\right.$ Lat, $84^{\circ} 50^{\prime}$ W Long), NE of Riverdale, Gratiot Co., Michigan. Samples from bog that contained mastodon bones, overlying sand covered with greenish gyttja and peat. Coll. 1965 by R. O. Kapp and S. Bushouse; subm. by R. O. Kapp and C. W. Hibbard, Univ. of Michigan.

M-1740. Thaller Mastodon site, wood $7120 \pm 250$ sample $\mathbf{A}$

5170 B.C.

Wood from depth of $30 \mathrm{~cm}$ below present land surface.

M-1741. Thaller Mastodon site, wood

$7220 \pm 250$

Wood from depth of $60 \mathrm{~cm}$ below present land surface in peat.

Peat from depth of 80 to $90 \mathrm{~cm}$ below present land surface. 
M-1743. Thaller Mastodon site, gyttja

$11,200 \pm 400$

Gyti 9250 B.c.

Gerlo (lepth of 130 to $140 \mathrm{~cm}$ below present land surface. General Comment (ROK): dates of peat and wood seem accurate, but late of gyttja appears too early.

\section{Rappuhn Mastodon site series I, Michigan}

Peat from Rappuhn Mastodon site $\left(43^{\circ} 17^{\prime} \mathrm{N}\right.$ Lat, $83^{\circ} 11^{\prime} 30^{\prime \prime} \mathrm{W}$ Long), Lapeer Co., Michigan. From 3 horizons immediately above Amer. Mastodon skeleton and "wooden" platform. Bones lie on clay base at same level with wooden sticks that may indicate human activity, and are overlain by peat. Pollen in sediments associated with skull indicates spruce-fir forest. Remains appear to antedate climatic amelioration of early post-Glacial. Coll. 1965 and subm. by R. O. Kapp.

\section{M-1744. Rappuhn Mastodon, 12 to} $13 \frac{1}{2}$ in. depth

$9640 \pm 350$

7690 B.c. layer.

Peat from 12 to $131 / 2$ in. below present surface, just below plow

\section{M-1745. Rappuhn Mastodon, 15 to} $161 / 2$ in. depth

$10,450 \pm 400$ 8500 в.C.

Peat from 15 to $161 / 2$ in. below present surface.

\section{M-1746. Rappuhn Mastodon, 20 to $10,730 \pm 400$ 22 in. depth \\ 8780 B.c.}

Peat from 20 to $22 \mathrm{in}$. below present soil surface at base of deepest pocket of peat, immediately upon and beneath "platform timbers." General Comment (ROK): dates coincide with uppermost portion of late Glacial spruce pollen zone. Most dated pollen diagrams from S Great Lakes region indicate major climatic amelioration occurred around 10,000 в.P.

\section{Rappuhn Mastodon series II, Michigan}

Bone and wood from the Rappuhn mastodon $\left(43^{\circ} 15^{\prime} \mathrm{N}\right.$ Iat, $83^{\circ}$ 15' W Long), T10N, R11E, NE $1 / 4$ SW $1 / 4$ Sec. 21, Clifford Twp., Lapeer Co., Michigan. Coll. 1965 and subm. by W. L. Wittry, Cranbrook Inst. of Sci., Bloomfield Hills, Michigan.

\section{M-1778. $\quad 9900 \pm 400$}

Mandibular fragment of $13 / 4 \mathrm{lb}$ in SE quadrant, disturbed by plow.

Mandibular fragment of $5 / 8 \mathrm{lb}$ in SE quadrant, clisturbed by plow.

\section{M-1780. Rappuhn Mastodon, $10.750 \pm 400$}

Wood stick from Square 140R100.
M-1781. Rappuhn Mastodon,
Wood stick from Square 140R100.
$10,750 \pm 400$ 
M-1782. Rappuhn Mastodon, Square 140R100 8450 B.c.

Wood stick from Square 140R100.

M-1783. Rappuhn Mastodon, Left Tusk

$9250 \pm 350$

(3) 7300 B.C. Inner and outer "rings" are present. Diameter of cavity is $2.5 \times 2.2$ in. Possible contamination from rootlets in cavity and on outer surface. Also bacterial growth on outer surface of outer ring. Ciut section 6.5 to 6.3 in. cliameter and 3.1 to 3.9 in. thick.

General Comment (WLW): mastodon bones were cut, partially charred, and scattered, which is interpreted as results of butchering (Wittry, 1965). Bones and platform of wood poles, believed laid down by man at time of mastodon's death, directly overlie till and are overlain by peat (M-1744 to M-1746, Michigan XII). Dates of wood poles are considered more reliable than those of bone and ivory.

\section{M-1753. Munro Buried Bryophyte Community, $\quad 9960 \pm 350$ Michigan \\ 8010 B.C.}

Several species of moss (icl. by Howard Crumm, Univ. of Michigan) from Munro Twp. (45 $38^{\circ} \mathrm{N}$ Lat, $84^{\circ} 41^{\prime} \mathrm{W}$ Long), center of Sec. 4, T37N, R3W, ('heboygan Cio., Michigan. Alt. 740 lt. Moss bed overlies pre-Valders outwash with a soil profile and underlies Valders till; and sediments of Iake Algonquin. Coll. 1965 and subm. by Robert Zahner, Univ. of Michigan. Comments (RZ): date does not conform to stratigraphic position of moss. (JBG): 2nd and 3rd runs on same material were each $10,700 \pm 350$.

\section{M-1807. Fitchburg Park, Michigan}

$10,890 \pm 350$ 8940 B.C.

Wood from Fitchburg Park $\left(42^{\circ} 26^{\prime} \mathrm{N}\right.$ Lat, $84^{\circ} 17^{\prime} \mathrm{W}$ Long), NE $1 / 4$ of Sec. 35, Bunkerhill Twp., Ingham Co., Michigan. Gnawed wood found $6 \mathrm{ft}$ below topsoil, peat, and muck. Coll. 1966 by J. J. Huffine; subm. by R. H. Baker, Michigan State Univ. Comment (RHB): wood might have been chewed by large extinct beaver (Castoroides) which formerly roamed Michigan.

\section{M-1831. Upton Creek Mouth (46 KA 60), $\quad 9000 \pm 350$ West Virginia \\ $\mathbf{7 0 5 0}$ B.C.}

Wood from Upton Cireek at W edge of city of So. Charleston, between U.S. Route 60 and Kanawha River, West Virginia ( $38^{\circ} 21^{\prime} \mathrm{N}$ Lat, $81^{\circ} 45^{\prime} \mathrm{W}$ Long). Fragment in lake sediments at $27.5 \mathrm{ft}$ brought up in coring. Coll. 1965 and subm. by E. V. McMichael, West Virginia Univ. Comment (EVM): date is within expected age.

M-1833. Lake Monongahela Terrace Deposit, $\quad 22,000 \pm 1000$ West Virginia 20,050 B.C.

Wood fragments and head of fruit (ball) of Plantaus occidentalis from sediments of ancient Lake Monogahela $\left(39^{\circ} 37^{\prime} 30^{\prime \prime} \mathrm{N}\right.$ Lat, $80^{\circ} 0^{\prime}$ 
W Long), Morgantown, West Virginia, 9800 It $\mathrm{N}$ of $\mathrm{N}$ Lat, and $8000 \mathrm{ft}$ E of W Long. Comment: geologists assumed sediments are of Kansan age, but recent pollen studies suggest a Wisconsin date (Cilendening. Renton, and Parsons, in press). Coll. 1966 by William Gwilliam; subm. by L. V. McMichael.

\section{M-1886. Taku Glacier, Alaska}

$1080 \pm 120$

Log of Alaska yellow cedar (Chamaecyparis nootkateneas) from ice and rock debris at Taku Glacier terminus $\left(58^{\circ} 26^{\prime} \mathrm{N}\right.$ Lat, $134^{\circ} 2^{\prime} \mathrm{W}$ Long), Juneau Burrough, Alaska. May be several thousand yr old, incorporated into glacier during advance; or, may be recent, floated to terminus by tidal action and trapped in highly unstable debris pushed up by the advancing glacier. Coll 1966 and subm. by M. M. Miller and J. H. Anclerson, Michigan State Univ. Comment (MMM): tree apparently grew during glacial recession, and became incorporated during a readvance.

\section{M-1926. Taku B glacier, Alaska}

$3900 \pm 170$

Soil sample from NW arm of Taku B glacier (58 2. $4^{\prime} \mathrm{N}$ Lat, $134^{\circ}$ 10' W Long), Alaska (Lietzke and Whiteside, 1967; Miller, 1966). Coll. 1966 by D. A. Lietzke and M. M. Miller; subm. by M. Miller.

\section{M-1888. St. James Coast Guard Station. $\quad 6788 \pm 250$ Michigan 4838 B.c.}

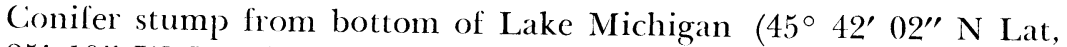
$85^{\circ} 25^{\prime} 10^{\prime \prime} \mathrm{W}$ Long), $4.5 \mathrm{mi}$. ESE of St. James Coast Guard Station, Beaver Island, Michigan. Found in $32 \mathrm{ft}$ of water, in growth position, partly covered by sediment. Stump is probably Pinus resinosa (F. Brunett, Mus. of Anthropol., Univ. of Mich.). Should date shoreline cluring rise of Lake Michigan from Chippewa low-water stage to Nipissing stage. Coll. 1966 by I. H. Somers; subm. by J. I. Hough, Univ. of Michigan. Comment (JIH): date seems correct.

\section{Taylor Valley series, Antarctica}

Mummified skin and flippers of seals (Lobodon carcinophaga and Leptonychotes weddelli) from Taylor Valley $\left(77^{\circ} 40-43^{\prime} \mathrm{S}\right.$ Lat, $162^{\circ}$ $30-45^{\prime}$ E Long), at foot of Seuss glacier, Lake Bonney, and Nussbaum Riegel, Antarctica. Expedition supported by NSF grant No. GB 2647. Coll. 1966 by T. Blair; subm. by M. A. Marini, M. F. Orr, and E. I. Coe, Northwestern Univ.

\section{M-1912. Sample 1}

$845 \pm 100$

Desiccated Crabeater seal flipper, taken from side next to ground; carcass well preserved. 
M-1913. Sample 2

Desiccated Crabeater seal flipper, also in contact with ground; carcass weathered.

M-1914. Sample 3

$1200 \pm 120$

Desiccated Crabeater seal flipper, taken from sicle away from ground; carcass weathered.

M-1915. Sample 4

$1045 \pm 120$

Desiccated Crabeater seal flipper, on side away from ground; carcass weathered.

M-1916. Sample 5

$2150 \pm 200$

Desiccated Crabeater seal flipper, taken from side away from ground. Carcass lay in small valley or depression and was fairly well preserved.

M-1917. Sample 6

$1155 \pm 120$

Desiccated seal skin and connective tissue; a few scattered remnants of carcass exposed to wind erosion on side of hill.

M-1918. Sample 7

$1845 \pm 140$

Desiccated Crabeater seal skin, taken from side away from grouncl; carcass weathered.

M-1919. Sample 8

$2045 \pm 140$

Desiccated Weddlell seal skin, taken from side away from ground; carcass weathered.

M-1920. Sample 9

$615 \pm 100$

Crabeater seal skin, from side away from ground; animal had been dead no longer than one year; frozen carcass was in excellent state of preservation.

General Comment (ELC): dates are satisfactory and indicate that seals wandered in at random and that degree of preservation is not closely related to age. Possibly seepage of ground water containing carbonate could have contaminated parts in contact with ground and have lowered their apparent age. The 615 B.P. date (M-1920) clearly suggests seals are obtaining part of their carbon from old sources.

A.D. 1720

$230+100$

M-1921. Mendenhall Glacier, Alaska

A.D. $1650 \mathrm{~N}$

Wood from Site IIa (58 $24^{\prime}$ N Lat, $134^{\circ} 35^{\prime}$ W Long), Mendenhall glacier, Juneau Icefield, Alaska. Sample imbedded in glacial-fluvial gravel and overridden (Miller, Anderson, and Egan, 1967; Miller, 1966). Coll. 1964 and subm. by M. M. Miller. 


\section{Davidson Glacier series, Alaska}

Wood and root close to Davidson Glacier terminus $\left(58^{\circ} 55^{\prime} \mathrm{N}\right.$ Lat, $135^{\circ} 25^{\prime}$ W Long), W side of N Lynn Canal, SE Alaska. Samples are from ancient lorest destroyed by glacier (Miller, Anderson, and Egan, 1967; Miller, 1966). Cioll. 1965 and 1966 and subm. by C. P. Egan and M. M. Miller.

\section{M-1922. Davidson Glacier, buried forest horizon}

$$
\begin{aligned}
& 760 \pm 100 \\
& \text { A.D. } 1190 \\
& \text { A.D. } 1225 \mathrm{~N}
\end{aligned}
$$

Section of trunk of young tree (probably Tsuga heterophylla or Picea sitchensis) from main buried forest horizon. Sample was overlain by $1 \mathrm{~m}$ of gravel.

\section{A.D. 1390}

M-1923. Davidson Glacier, depth $3 \mathrm{~m}$ A.D. $1410 \mathrm{~N}$ (a. $9 \mathrm{~m}$.

Flattened root (probably $T$. heterophylla or P. sitchensis) from depth

\section{M-1924. Davidson Glacier, surface}

Wood (probably $T$. heterophylla or $P$. sitchensis) near base of icesheared tree trunk. Sample was exposed at surface at collection, but prior to being exhumed by stream action, it had been buried by ca. $5 \mathrm{~m}$ of till and glacial outwash.

\section{M-1925. Gilkey and Vaughan Lewis glaciers, $\quad 2100 \pm 140$ Alaska

Soil from spur above conjunction of Gilkey and Vaughan Lewis glaciers (58 $47^{\prime} \mathrm{N}$ Lat, $134^{\circ} 30^{\prime} \mathrm{W}$ Long), about 500 to 800 ft below Camp 18 on Juneau Icefield, Alaska (Lietzke and Whiteside, 1967; Miller, 1966). Coll. 1966 by D. A. I ietzke and M. M. Miller; subm. by M. M. Miller.

II. ARCHAEOLOGIC SAMPLES

Upper Mississippi Valley and Great Lakes

$$
850 \pm 100
$$

\section{M-982. Monk's Mound, Cahokia, Illinois \\ A.D. 1100}

Charcoal from Monk's Mound (38 $39^{\prime} 37^{\prime \prime} \mathrm{N}$ Lat, $90^{\circ} 3^{\prime} 50^{\prime \prime} \mathrm{W}$ Long), SW 1/4 of SE 1/4, Sec. 35, T3N, R9W, Cahokia, Madison Co., Illinois. Sample from layer of charcoal 8 to $10 \mathrm{in}$. above a burnt sand floor, $1 / 2$ in. thick, overlying ca. 1.5 in. of burnt area. Floor is about $6 \mathrm{ft}$ below surface of mound terrace on W side of Monk's Mound. Floor and charcoal are eroding. One sherd (St. Clair Plain?) was associated; should date Middle Mississippi. Coll. 1958 and subm. by D. F. Morse. 
Jonesville, Arkansas. Comment (JBG): date is comparable to those from top of Monk's Mound (M-1636 and M-1637, Crane and Griffin, 1966).

\section{M-1084. West Twin Lake mound group, $\quad 1000 \pm 100$ Michigan \\ A.D. 950}

Human femur probably from West I ake Nound $8\left(44^{\circ} 47^{\prime} \mathrm{N}\right.$ Lat, $84^{\circ} 20^{\prime}$ W Long) SW $1 / 4$ SE $1 / 4$ Sec. 20, Albert Twp., Montmorency Co., Michigan (Hinsdale, 1930). Mound 8 contained disarticulated multiple burial associated with Late Point Peninsula-like material, uniclentified pottery vessel, Port Maitland-like projectile points, and bone harpoons. Site is group of 8 mounds with burials at various times, alternating with layers of charcoal which occur as lenses over large surface of mounds at various levels. Sample was drawn from 2 femurs catalogued as "119 parts of skeletons, Catalog No. 2322." Cioll. 1927 and 1928 by W. B. Hinstale: subm. by M. I. Papworth, Oberlin Ciollege. Comment (JBG): date is satisfactory for this Late Woodland occupation in $\mathrm{N}$ central Iower Peninsula of Michigan.

\section{M-1399. Steed-Kisker site, Missouri}

$720 \pm 100$

Charcoal from floor of House 3, Steed-Kisker site $\left(39^{\circ} 17^{\prime} 15^{\prime \prime} \mathrm{N}\right.$

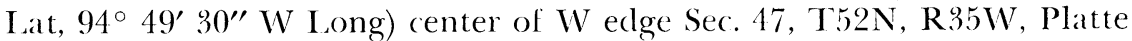
Co., Missouri. Coll. 1962 and subm. by J. M. Shippee, Univ. of Missouri. Comment (JBG): date agrees with earlier assays for this Mississippian site. See Mich. XI.

M-1483. Aring Pearl site, Missouri

$940 \pm 100$

Charcoal from Aring Pearl site (23 Pl 43), (39 $15^{\prime} \mathrm{N}$ Lat, $94^{\circ} 48^{\prime}$ 15" W Long) NE corner Sec. 10, T51N, R35W, Platte Co., Missouri. Sample recovered from small deposit of gray ash at bottom of refusefilled pit exposed by deep plowing of Mr. Pearl. Pit depth was 63 in. from present surface or $12 \mathrm{in}$. of silt over $15 \mathrm{in}$. of deep midden deposit over 36 in.-deep pit. In association was restorable Hopewell pot, fragments of another, flint scraper, bone scrap, and burned limestone fragments covering site. Site large, extending along old Platte River channel for $1 / 2 \mathrm{mi}$. Not excavated, but probably one component, comparable to Trowbridge and Renner (Wedel, 1943). Babcock mounds (Wedel, 1943) on bluff $1 / 4 \mathrm{mi}$. to east. Pearl and Nolan mounds on ridges $3 / 4$ to $1 \mathrm{mi}$. to SE. According to R. B. Aker, layers of sediment cover consecutive layers of cultural debris to depth of $5 \mathrm{ft}$. Pottery seems to be same from top to bottom. Coll. 1963 and subm. by J. M. Shippee. Comment (JMS): late is not applicable to cultural material for reasons which have not been satisfactorily determined.

M-1602. Aring Pearl site, Missouri

$1220 \pm 120$

A.D. 730

Charred wood and grass from Aring Pearl site (23 P1 43), (39 $\left.19^{\circ}\right)^{\prime}$ N Lat, $94^{\circ} 48^{\prime} 15^{\prime \prime}$ W Long) NE corner Sec. 10, T51N, R35W, Platte Co., Missouri. From bottom of deep pit about $5 \mathrm{ft}$ below present surface. 
Overburden of river-borne silt $18 \mathrm{in}$. decp. Sides of pit burned from internal fire. Associated material: vertical compound vessel, antler tool probably for making rocker stamp, bowl of stone platform pipe. Sample may date Stone Vault mounds excavated by Wedel in 1938 (Wedel, 1943) on bluffs $1 / 2$ to $1 \mathrm{mi}$. E., thought to be Hopewell. Coll. 1964 by R. B. Aker; subm. by J. M. Shippee. Comment (JMS): date is not applicable to cultural material for reasons which have not been satisfactorily determined.

\section{M-1485. Montezuma Mound 9, Illinois}

Charred wood from Montezuma Mound $9\left(39^{\circ} 32^{\prime} 58^{\prime \prime} \mathrm{N}\right.$ Lat, $90^{\circ}$ $34^{\prime} 52^{\prime \prime}$ W Long), Pike Co., Ill. Charcoal fragments from oak log, 12 to 14 in. diameter, from crib tomb. Only scattered human remains such as finger and toe bones were recovered. Most skeletal material was removed after exposure in crib. No artifacts were in tomb, which is of Hopewell construction. Coll. 1956 and subm. by Gregory Perino, Tulsa, Oklahoma. Comment (GP): clate seems slightly carly for this mound group but sample may be from inner section of $\log$.

\section{M-1494. Young site, Missouri}

$1610 \pm 130$

Charred stick from Young site (23 Pl 4) $\left(39^{\circ} 13^{\prime} \mathrm{N}\right.$ Iat, $91^{\circ} 18^{\prime} \mathrm{W}$ Long), SW 1/4 Sec. 39, T51N, R34W, Platte Co., Missouri. Found in burned rock zonc, below 12 to 18 in. of humus with Late Hopewell pottery (Wedel, 1943). Coll. 1938 by W. R. Wedel; subm. by J. M. Shippec. Comment (JMS): date on this site confirms that these mounds and Hopewell complex are contemporaneous. Stone vault in which sample was found was unlike carefully-made Renner mounds and nearby village pottery is not classical Hopewell.

\section{Research Cave ( 23 CY 64) series, Missouri}

Charcoal from Rescarch Cave ( $38^{\circ} 44^{\prime} \mathrm{N}$ Lat, $91^{\circ} 45^{\prime} \mathrm{W}$ Iong), NE corner Sec. 30, T46N, R7W, Calloway Co., Missouri. Coll. in 1950's and subm. by J. M. Shippee.

\section{Research Cave, Square 130R17, $\quad 8120 \pm 350$ 54 to 60 in. depth \\ 6170 B.C.}

Charcoal from Square 130R17, 54 to $60 \mathrm{in.}$ depth; should date deep level of occupation well back in cave.

\section{M-1496. Research Cave, Square 130R17, $8190 \pm 400$ 54 to 60 in. depth \\ 6240 в.C.}

Charcoal from Square $190 \mathrm{R} 17,54$ to $60 \mathrm{in}$. depth. Will date Dalton point and 2 points from old occupational level.

\section{M-1497. Research Cave, Square 130R17, $\quad 9130 \pm 300$ 60 to 65 in. depth \\ 7180 B.C.}

Charcoal from Square 130R17, 60 to 65 in. depth; should date bottom level in cave which has Dalton and lanceolate points.

General Comment (JMS): dates are satisfactory. 
M-1498. North site, Illinois

Wood charcoal from North site (38 $35^{\prime} \mathrm{N}$ Lat, $89^{\circ} 21^{\prime} \mathrm{W}$ Long), Cilinton Cio., Illinois. Sample was charred $\log$ that lay at tomb floor level on $\mathrm{N}$ side of Hopewell structure in Mound 5 . Remains of 5 individuals, all bundle re-burials and charred, lay in individual groups. Two were children. Artifacts on tomb floor apart from burials consisted of Hopewell zoned dentate stamped jar; smooth and thin conical jar with smoothed-over cordmarking and rim nodes, copper adt, small copper pin, and 2 small sheets of mica. Coll. 1963 by Vernon Carpenter: subm. by Gregory Perino. Comment (GP): clate seems early but J. B. Criffin thinks it may have been from center of large log since charred remains were less than 6 in. in diameter and logs used in tomb construction were never less than $16 \mathrm{in}$. in cliameter; most were $24 \mathrm{in}$. or more.

\section{M-1558. McGraw village site, Ohio}

$1720 \div 140$

Charcoal from the McGraw village site $\left(39^{\circ} 19^{\prime} \mathrm{N}\right.$ Lat, $82^{\circ} 5\left(6^{\prime} \mathrm{W}\right.$ Long), on Alva McGraw farm on Route 35 and 50, 11/2 mi. SE of Chillicothe in Ross Co., Ohio. Site on river bottom of $\mathrm{W}$ bank of Scioto River. From dense homogeneous midclen deposit sealed off from surface by 2 layers of sterile flood (leposit. First known and excavated Ohio Hoperell settlement site. Site also yielded corn, establishing agricultural basis of Hopewell. Dates on site are discussed in publication on site (Pruler, 1965). Coll. 1963 and subm. by O. H. Prufer, Case Inst. of Technol., Cileveland. Comment (OHP): date is satisfactory and within range of earlier assays.

\section{Peisker site series, Illinois}

Wood charcoal from the Peisker site $\left(39^{\circ} 5^{\prime} 26^{\prime \prime} \mathrm{N}\right.$ Lat, $90^{\circ} 35^{\prime} \cdot 16^{\prime \prime}$ W Iong), Calhoun Co., Illinois. Single component habitation site beneath Mound 3 is believed to represent early expression of Hopewellian phase of Havana tradition. Associated pottery is Havana and grittempered Hopewell series. Coll. 1963 by (iregory Perino; subm. by Stuart Struever, Northwestern Univ.

\section{M-1569. Peisker site, Feature I}

$1700+120$

Charcoal representing in situ remnant of hearth (Feature l) occurring as part of pre-mound habitation site beneath Mound 3 .

\section{M-1570. Peisker site, Feature 2}

$1880 \pm 120$

Charcoal representing in situ remmant of hearth (Feature 2) occurring as part of pre-mound habitation site beneath Mound 3.

General Comment (SS): dates fall within well-documented time span of later Hopewellian phase of Pike tradition. Hopewell-Pike occupation area was excavated immediately adjacent to Mound 3 at Peisker, and these dates appear to be associated with that area. 


\section{Salts Cave site series I, Kentucky}

Human feces from Salts Cave (37 $11^{\prime} \mathrm{N}$ Lat, $86^{\circ} 3^{\prime} \mathrm{W}$ Long), Hart and Edmondson Co., Kentucky (Watson and Yarnell, 1966). Cultural material recovered so far not diagnostic. Dating will help determine time of use of cave for mining gypsum and other salts, and will check dates already obtained for Salts and Mammoth caves (Benington, Melton, and Watson, 1962). Coll. 1963 by P. J. Watson, R. A. Yarnell, and R. L. Hall; subm. by P. J. Watson, 756 Harvard, University City, Missouri.

\section{M-1573. Salts Cave, Upper}

Human feces, containing Iva, sunllower, hickory nutshell, grape seeds, squash seeds, and Chenopod; found near survey point P-58, on dirt between breakdown blocks in sheltered location, covcred with gypsum needles in Upper Salts (SCU-38).

\section{M-1574. Salts Cave, Upper}

$2570 \pm 140$

Human feces, containing sunflower, Phalaris, Chenopod, Iva, sumac (‡) berries, hickory nutshell, and fish scales; found near survey points P-63-64, under breakdown on right sicle of passage in Upper Salts (SCL T-39).

\section{M-1777. Salts Cave, Upper}

Human feces, conttining Chenopodt, marshelder and sunflower. and hickory nutshell, panic grass seeds, fish scales, and feather; found near P-38 in Upper Salts (SCU-105).

\section{M-1577. Salts Cave, Middle}

Human feces, containing sunflower, Iva, grape seeds, Phalaris, gras (?) stem base, fish scales, and beetle pupa fragments; found at $\mathrm{A}-60$ in Middle Salts (SCM-5).

M-1770. Salts Cave, Middle

$2660 \pm 140$

710 B.c. (SC:M-1).

Human feces found at survey point A-42 in Middle Salts Cave General Comment (PJW): determinations indicate an early Woodland period for Salts Cave variant of interesting dietary complex noted 30 yr ago by Volney Jones (1936). Included in prehistoric feces from Salts Cave are wild seeds and nuts plus series of cultivated species (squash, sunflower, possibly Chenopod and Iva, and, in comparable but undated fecal specimens, gourd). M-1573 date is one of earliest dated occurrences in castern U.S. of member (squash) of important horticultural complex which spread to No. America from Mexico.

\section{Salts Cave site series II, Kentucky}

Cane and wood from Salts Cave (37 $17^{\prime} \mathrm{N}$ Lat, $86^{\circ} 3^{\prime} \mathrm{W}$ Long), Hart and Edmondson Co., Kentucky. Cultural material recovered so far not diagnostic. Dating will help determine time span of mining gypsum 
and other salts, and will check dates already obtained for Salts and Mammoth Caves (Benington, Melton, and Watson, 1962). Present series of dates on cane and wood will also check first determinations of dried prehistoric feces. Coll. 1963 by R. L. Hall and P. J. Watson; subm. by P. J. Watson.

M-1584. Salts Cave, Upper

Cane (SCU-55) from Upper Salts, Test A, 0 to $10 \mathrm{~cm}$.

M-1585. Salts Cave, Upper

560 B.C.

Cane (SCU-80) from Upper Salts, Test A, 30 to $40 \mathrm{~cm}$.

$2430 \pm 130$

480 B.C.

\section{M-1586. Salts Cave, Upper}

$2840 \pm 150$

Cane (SCU-148) from Upper Salts, Test A, 70 to $80 \mathrm{~cm}$.

\section{M-1587. Salts Cave, Upper}

$2520 \pm 140$

Wood from Test A, Square $1,140 \mathrm{~cm}$. beneath surface (SCU-15i).

\section{M-1588. Salts Cave, Lower}

$$
\mathbf{2 7 2 0} \pm \mathbf{1 4 0}
$$

Wood from small log survey point $\mathrm{I}-76$ plus $2 \mathrm{~m}$ in Lower Salts (SCL-8).

\section{M-1589. Salts Cave, Lower}

Wood and bark lragments from survey point $I-67$ in Lower Salts (SCL -9$)$.

General Comment (PJW): these determinations agree with previous dates for Salts and Mammoth Caves, and with those for Newt Kash Hollow shelter ( Benington, Melton, and Watson, 1962; Michigan I). They substantiate Schwartz's suggestion that most activity in caves took place during Early Woodland period (Schwartz, 1960). Series II cane and wood determinations agree with Series I of prehistoric fecal material.

\section{Spencer Lake Mound series, Wisconsin}

Charred wood from Spencer Lake Mound $\left(46^{\circ} 0^{\prime} \mathrm{N}\right.$ Lat, $92^{\circ} 30^{\prime} \mathrm{W}$ Long), N shore Spencer Lake, S 1/2 sec. 26, T38N, R15W, La Follette Twp., Burnett Co., Wisconsin. Mound had 4 strata or mounds. Clam River focus, Late Woodland, possibly proto-historic (McKern, 1963). Coll. 1936 by W. C. McKern; subm. by Robert Ritzenthaler, Milwaukee Public Mus.

\section{M-1581. Spencer Lake Mound, Mound 1 A.D. 580}

$1370 \pm 110$

Charred wood from Mound 1, Feature 10 on floor of mound.

M-1582. Spencer Lake Mound, Mound 1

$1420 \pm 150$

Charred wood from floor of Mound 1. 
M-1583. Spencer Lake Mound, Mound 1

$1460 \pm 120$

Charred wood from Mound 1, Burial 7.

General Comment (RR): dates are earlier than expected, but very acceptable and not in conflict with archaeological probability. Ciloseness of dates adds to credibility.

\section{M-1596. Spencer Lake Mound, Wisconsin}

A.D. 1100

$840 \pm 100$

Charred bone from Spencer Lake Mound $\left(46^{\circ} 0^{\prime} \mathrm{N}\right.$ Lat, $92^{\circ} 30^{\prime}$ W Long), $\mathrm{N}$ shore Spencer Lake, S 1/2 (near line dividing SW $1 / 4$ and SE 1/4) Sec. 26, T38N, R15W, La Follette Twp., Burnett Co., Wisconsin. From Burial 18, Stratum 3, stratified mound of Clam River focus, Late Woodland and possibly proto-historic (McKern, 1963). Coll. 1936 by W. C. McKern; subm. by Robert Ritzenthaler. Comments (RR): in light of 3 charcoal samples run by Michigan (M-1581, A.D. 580; M-1582, A.D. 530; M-1583, A.D. 490) and 2 charcoal samples run by Wisconsin (A.D. 750 to 930$)$, A.D. 1100 obtained on charred bone appears to be deviant on late side. (JBG): Stratum 3 includes Burial 18 and Burial 7 (M-1583); these were deposited in mound after wood specimens (M-1581 and M-1582).

\section{Hannah site series, Illinois}

Wood, bark, and shell from Hannah site $\left(41^{\circ} 50^{\prime} \mathrm{N}\right.$ Lat, $89^{\circ} 34^{\prime} \mathrm{W}$ Long), SW 1/4 Sec. 22, T10N, R8E, Medina Twp., Peoria Co., Illinois. Site is late Early or early Middle Hopewell. Coll. 1964 and subm. by D. F. Morse, Ilaho State Univ.

\section{M-1627. Hannah site, Tomb 1}

$1860 \pm 130$

Bark from Tomb 1, Burial 4 beneath copper adz.

$$
\text { A.D. } 90
$$

\section{M-1628. Hannah site, Tomb 2}

$1790 \pm 200$

Bark from Tomb 2, N side; should be earlier than Tomb 1.

\section{M-1630. Hannah site, Tomb 2}

$1820 \pm 120$

Wood from Tomb 2, 2nd N-S log from W. Dates 2nd roof of tomb; and therefore probably construction of primary mound, if it is not earlier.

M-1631. Hannah site, Tomb 2

$1720 \pm 130$

Wood from Tomb 2, 4th N-S log from W. Dates 2nd roof.

\section{M-1632. Hannah site, Tomb 2}

$2300 \pm 130$

350 в.C.

Shell of fresh water mussels from Tomb 2, S side. Earliest sample, from beginning of use of Tomb 2.

General Comment (DFM): dates are from 2 tombs in single mound salvaged in 1964 (Morse and Morse, 1965). Four of five dates cluster around 
first two centuries A.D. which is 1 to 2 centuries later than clates obtained from similar complexes in nearby Dickison mound group (Bluhm and Beeson, 1960). Dating expected on basis of tomb construction and artifact interment.

\section{Schultz site (20 Sa 2) series, Michigan}

Charcoal and charred nutshells from the Schultz site $\left(43^{\circ} 23^{\prime} \mathrm{N}\right.$ Lat, $83^{\circ} 59^{\prime} \mathrm{W}$ Long), S 1/2 NE 1/4 Sec. 3, T11N, R4E, Saginaw Co., Michigan. Coll. 1964 by field party; subm. by J. E. Fitting, Mus. of Anthropol., Univ. of Michigan.

\section{M-1644. Schultz site, Unit 510E570, 4 ft depth}

$1570 \pm 120$ A.D. 380

Charred nutshells, primarily black walnut with some butternut, from Unit 510E570, Feature 64-74, $4 \mathrm{ft}$ below surface near bottom of filled river channel. Distinct hearth at lowest level of culture-bearing deposits. Though no quantity of cultural material was found in this feature, thick, plain, and broad line-incised sherds were found at same level in several nearby features (64-50 and 64-72).

\section{M-1646. Schultz site, Unit 510E570,}

\section{0 ft depth}

$1640 \pm 120$

\section{A.D. 310}

Charcoal from Unit 5105570, Feature 64-21, $2 \mathrm{ft}$ below surface in area of filled river channel. Well-defined feature containing Hopewell rim with rocker stamping, crude side-notched points, and dense concentration of fish bone. Should date Hopewell phase of site sequence.

\section{M-1647. Schultz site, Unit 510E570,}

\section{6 ft depth}

$1500 \pm 200$

\section{A.D. 450}

Charcoal from Unit 510E570, Feature 64-17, at $1.6 \mathrm{ft}$ below surface in area of filled river channel and overlying M-1646. Feature had plain rocker-stamped body sherds, the base of corner notched point, and large quantities of fish bone. Should date last phase of Middle Woodland occupation.

\section{M-1648. Schultz site, Unit 540E585. \\ $1.8 \mathrm{ft}$ depth}

$770 \pm 100$

\section{A.D. 1180}

Charcoal from Unit 540E585, Feature 64-75, $1.8 \mathrm{ft}$ below surface on old river bank. Feature at base of plow zone, partially plowed away. Restorable castellated Wayne Ware vessel and several rim fragments of collared (but not castellated) Macomb Linear Corded vessel were found. Material is considerably younger than most material at site and should furnish most recent date.

General Comment (JEF): with execption of M-1644, dates are well within expected ranges. M-1644 is perplexing. It is from a level $2 \mathrm{ft}$ below $\mathrm{M}-1647$ and associated with ceramics consistently stratified between Early Woodland (Marion Thick) and Middle Woodland types. It seems both relatively and absolutely out of place. 
M-1682. Kane site, Illinois

Charred wood post from Kane site (MS 194), $\left(38^{\circ} 45^{\prime} 20^{\prime \prime} \times\right.$ Iat, $90^{\circ} 0^{\prime} 10^{\prime \prime} \mathrm{W}$ Long) Madison Co., Illinois. From floor of House 5, structure about $6 \mathrm{ft}$ sq. with excavated floor and small single-post construction. Sample should date Late Woodland ("Bluff") complex in No. American Bottom area, existing just prior to Mississippian development at Cahokia or contemporary with early phase of this clevelopment, at 1000 to 1200 B.P. Coll. 1963 by P. J. Munson; subm. by R. L. Hall, Illinois State Mus. Comment (RLH): House 5 was believed to be earlier than this, but date is consistent with another of A.D. $1130 \pm 95$ (I-2011, unpub.) for House 1 , which was believed, on typological grounds, to be slightly later; these 2 dates are within correct ranges. Kane village is probably contemporary with Old Village occupation at Cahokia site, though showing little evidence of acculturation.

\section{Stolle Quarry site series, Illinois}

Charred wood and nut shell from Stolle Quarry site (S 130). (38 $32^{\prime} 35^{\prime \prime} \mathrm{N}$ Lat, $90^{\circ} 9^{\prime} 40^{\prime \prime} \mathrm{W}$ Long), St. Clair Co., Illinois. Samples should date Late Woodland horizon predating Mississippian developments in American Bottom at 1200 to 1400 B.P. Coll. 1963 and subm. by R. L. Hall.

\section{M-1683. Stolle Quarry, Composite sample}

$1050 \pm 110$

Charred wood and hickory nut shells from Features 2-5, 7 , and 10. All features produced similar cordmarked, grog-tempered pottery with frequent inner lip decoration.

\section{M-1684. Stolle Quarry, Feature 9}

$1230=110$

Charred wood and pecan from Feature 9, pit intrusive into basin fill and through floor of House 1. Associated pottery is essentially identical to M-1683.

General Comment (RLH): average of dates (A.D. 810) is slightly later than expected but agrees with average date of A.D. 83.3 for 3 samples from Hilltop site in St. Charles Co., Missouri (M-619, Mich. V; M-620, M-621, Mich. IX); which, typologically, should cross-date with Stolle Quarry.

\section{M-1685. Scovill site, Illinois}

$1500 \pm 120$

Charred wood from the Scovill site (F 106), (40 23' 45" X Lat, $90^{\circ} 12^{\prime} 55^{\prime \prime}$ W Long) Fulton Co., Illinois. From Feature 39, refuse-filled pit. Should date Woodland ceramic complex consisting almost entirely of Weaver ware (Wray and MacNeish, 1961). Coll. 1963 by P. J. Munson; subm. by R. L. Hall. Comment (RLH): about as expected. 


\section{Riverside Cemetery series, Michigan}

Charcoal, charred wood, and bark from Riverside Cemetery $\left(45^{\circ} 15^{\prime}\right.$ N Lat, $87^{\circ} 44^{\prime} \mathrm{W}$ Long), Menominee Co., Michigan. Coll. 1961 and 1962 and subm. by R. J. Hruska, Oshkosh Public Mus.

\section{M-1715. Riverside Cemetery, Feature 37}

$1950 \pm 130$

Ciharcoal is remains of 16 charred poles standing upright within burial pit. Iarge quantities of cremated bone were beneath flexed burial of adolescent. Beads, blades, and a copper celt were closely associated. Expected date: 100 to 500 B.c.

\section{M-1716. Riverside Cemetery, Feature 46 \\ $2050 \pm 140$ \\ 100 B.C.}

Charcoal from 2 charred vertical poles directly within pit fill at depth of 65 in. Burial pit was ocher-stained with 6 stemmed projectile points; no human remains were found.

M-1717. Riverside Cemetery, above Feature 27240 B.c.

Charred bark fragments of burial crypt containing flexed adult female, directly above Feature 27. Red ocher, a large copper awl, a sharpening stone, 2 salt-water shell beads, 8 large and 1 small blade were associated.

$$
2180 \pm 140
$$

M-1718. Riverside Cemetery, alıove Feature $30 \quad 130$ в.c.

Charred fragments of logs which were part of burial crypt above Feature 30 at depth of $55 \mathrm{in}$. Red ocher and 13 blades were associated with flexed adult with all but lower limbs destroyed.

\section{M-1719. Riverside Cemetery, above Feature $30 \quad 510$ B.c.

$$
2460 \pm 140
$$

Charred wood fragments from burial crypt above Feature 31 at depth of over 60 in. Burned birch bark was found above wood fragments, with awl holes and trace of lashing. Thirteen stone artifacts and enamel of adolescent teeth were in upper level. In lower level were fragments of adult male and lemale, beads, and 2 large animal tceth.

General Comment (JBG): see earlier date from this site (M-658) of 3040 \pm 900 в.P. or 1090 в.C. (Crane and Griffin, 1958).

\section{M-1721. Apple Creek site, Illinois \\ $1490 \pm 130$}

Charcoal from Apple Creek site $\left(39^{\circ} 22^{\prime} 15^{\prime \prime} \mathrm{N}\right.$ Lat, $90^{\circ} 32^{\prime} 22^{\prime \prime} \mathrm{W}$ Long), Green County, Illinois. Sample came from Feature 367b, in situ remnant of last fire burned in hearth associated with Pike House, which belongs to Hopewellian phase of Pike tradition, in Middle Woodland period. Coll. 1963 and subm. by S. Struever, Northwestern Univ. Comment (SS): date slightly later than expected, but identical to that of same charcoal specimen (OWU-105B, Ogden and Hay, 1967). 


\section{Schmidt site series (20 SA 192), Michigan}

Charcoal from Schmidt site (20 SA 192), (432 $21^{\prime} \mathrm{N}$ Lat, $84^{\circ} 55^{\prime} \mathrm{W}$ Long), T11N, R4E, NE 1/4 Sec. 19, Bridgeport Twp., Saginaw Co., Michigan. Probable association with preceramic Dustin archaeological assemblage at site. Dustin-type projectile points found at or above each sample level (Harrison, 1966). Coll. 1964 by Sidney Harrison and subm. for Mus. of Anthropol., Univ. of Michigan.

\section{M-1731. Schmidt site, Feature 7}

$6550 \pm 250$

Charcoal from Feature 7, 560E515, basin-shaped hearth stratigraphically associated with earliest preceramic occupation at site. Hearth extended from 2.15 to 3.0 ft below surface; most charcoal came from lower portion.

M-1732. Schmidt site, Feature 8

$6650 \pm 250$ 4700 B.c.

Charcoal from Feature 8, 560E515, basin-shaped hearth stratigraphically associated with earliest preceramic occupation at site.

\section{M-1733. Schmidt site, Unit 535E500}

$5400 \pm 200$

Charcoal from upper part of tan sand of earlicst occupation at 4 to $5 \mathrm{ft}$ below present surface.

\section{M-1734. Schmidt site, Feature 3}

$8100 \pm 500$

Charcoal from peclestal of Feature 3, small hearth in unit 560E505. General Comment (JBG): dates are substantially earlier than presumed occupation in post-Nipissing time. Source and nature of samples not clearly understood at this time.

\section{Bussinger site series, Michigan}

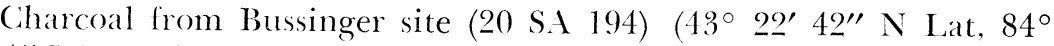
02' 5. W W Long), Saginatw Co., Michigan. This is a multiple component site. Coll. 1965 by A. H. Graves of Saginaw and C. Pomranky of Midland; subm. by J. E. Fitting.

\section{M-1755. Bussinger site, Michigan}

$660 \pm 100$ ressel.

Charcoal of white oak group found beneath a small Late Woodland

\section{M-1756. Bussinger site, Michigan}

$1460 \pm 120$

Charcoal of red oak group found in Feature A, a large unstratified pit with Saginaw-area late-Hopewell-style pottery in bottom.

\section{M-1796. Bussinger site, Michigan}

A.D. 1220

$730 \pm 100$

Charcoal from layer covering Burial 47 in pit ON, 60W. Associated with Burial 47 were 3 pots and 2 bone harpoons which have affinities with Intrusive Nound culture of Ohio. 
General Comment (JBG): date on M-1796 is too late by 700 to 400 y for Intrusive Mound culture but cultural association of burial may be with a later complex. M-1755 and M-1756 dates are satisfactory.

\section{M-1757. McCune village site, Ohio}

$630 \pm 100$

Wood charcoal from McCune village site $\left(39^{\circ} 19^{\prime} \mathrm{N}\right.$ Lat, $82^{\circ} 6^{\prime} \mathrm{WV}$ Long), Athens, Ohio. Sample found $1 \mathrm{ft} 2 \mathrm{in}$. beneath surface and plow zone on W Union Street in Athens, Ohio. Found above zone containing only Late Woodland sherds. Site represents Feurt phase component with fewer remains of earlier Baum phase and still earlier Middle or Late Woodland phase. Coll. 1964 and subm. by J. L. Murphy, Case Institute of Technology, Cileveland, Ohio. Comment (JLM): first $\mathrm{C}^{14}$ clate from a Feurt phase component, agrees with date of nearby Graham site, a Baum component, and strongly supports contention that Griffin's (1943) original Feurt focus is best considered a Feurt phase temporally intermediate between carlier Baum and Later Madisonville phases.

\section{M-1758. Whorley Earthwork (20 BR 6), $\quad 870 \pm 100$ Michigan \\ A.D. 1080}

Charcoal from Whorley Earthwork $\left(41^{\circ} 47^{\prime} \mathrm{N}\right.$ Lat, $85^{\circ} 9^{\prime} \mathrm{W}$ Long), Sec. 7, T8S, RTW, E shore of Gilead Lake, Branch Co., Michigan. From portion of burned post fragment No. 15 located in Trench E 5 (designated TE5) of NE extension of earthwork. In Stratigraphic Unit 3 (vellowish-red sandy loam) immediately below surface. Depth was $0.6 \mathrm{ft}$ below Datum I, $2 \mathrm{ft} \mathrm{W}$ and $0.5 \mathrm{ft} S$ of Datum I. Sample should clate construction of earthwork. Coll. 1965 by J. D. Speth; subm. by J. E. Fitting. Comment (JEF): date is acceptable; earliest for an earthwork in Michigan.

\section{M-1759. Carrigan Mound, Michigan}

$1270 \pm 120$

Charred wood (Quercus) from Carrigan Mound $\left(43^{\circ} 27^{\prime} \mathrm{N}\right.$ Lat, 85 38' W Long), NE 1/4 NE 1/4 Sec. 8, T12N, R11W, Croton Twp., Newaygo Co., Michigan. From bottom of burial pit, $8 \mathrm{ft}$ below Datum $A$ and in direct association with burial. Coll. 1965 and subm. by Earl J. Prahl for Mus. of Anthropol., Univ. of Michigan. Comment (EJP): dates early Late Woodland burial complex of Muskegon drainage (Prahl, 1966).

\section{M-1849. Carrigan Mound B, Michigan}

$2540 \pm 150$

Charcoal from Carrigan Mound B (20 NE 111) $\left(43^{\circ} 27^{\prime} \mathrm{N}\right.$ Lat. $85^{\circ}$ $38^{\prime}$ W Long), T12E, R1IN, NW 1/4 NW 1/4 Sec. 9, Newaygo Co., Michigan. From top of burial pit, Square F-2.3N $\times 5-1.3 \mathrm{E}$ and 3.55 to $3.85 \mathrm{ft}$ below line level. A cremated human burial in mound (Prahl, 1966). Coll. 1966 and subm. by E. J. Prahl. Comment (EJP): date contradicts formally held idea that 5 mounds at confluence of Big and Little Muskegon are of same cultural period. Carrigan A Mound, $150 \mathrm{ft}$ aray has 7 th century A.D. date. 


\section{Morrison site series, Ohio}

Charred matting and vegetable remains from the Morrison site $37^{\circ} 12^{\prime} 03^{\prime \prime} \mathrm{N}$ Lat, $82^{\circ} 51^{\prime} 04^{\prime \prime} \mathrm{W}$ Long), Franklin Twp., Ross Co., Ohio. Coll. 1965 and subm. by O. H. Prufer.

M-1760. Morrison site, Pit C

Charred matting from Pit C.

\section{M-1761. Morrison site, Pit $\mathrm{H}$}

Charred vegetable remains from $\mathrm{Pit} \mathrm{H}$ at 5 to $6 \mathrm{ft}$ depth. Corn, Late Woodland pottery, and one sherd of Madisonville Cordmarked found in pit. Lower levels had only Late Woodland cordmarked ware.

General Comment (OHP): the first impression that this site represents Late Woolland assemblage including a few Fort Ancient elements was not substantiated. These radiocarbon dates and 3 further dates indicate late temporal position of site. Additional dates yielded following values: OWVU-181, 472 \pm 17 (A.D. 1478); GXO-669a, $50 \pm 120$ (A.D. 1900); GXO$669 \mathrm{~b}, 30 \pm 160$ (A.D. 1920). Geochron samples came from same unit and charcoal material as M-1761. Clearly, site is very late, probably historic. On Evans Map of 1755, precise location of site id. as Indian settlement named Huricane Tom's Town; in 1751 Christopher Gist referred to this place as a small Delaware village, giving precise geographic data. Tentatively, we identify Morrison site with Hurricane Tom's Town.

\section{M-1768. Boven Earthworks (20 MA 7), Michigan}

A.D. 1470

$480 \pm 100$

Charcoal from Boven Earthworks (44 $15^{\prime} \mathrm{N}$ Lat, $85^{\circ} 5^{\prime} \mathrm{W}$ Long), SE $1 / 4$ SW 1/4 Sec. 26, T22N, R7W, Reider Twp., Missaukee Co., Michigan. From post molds of NW side of stockade. Should date late prehistoric occupation edge area, between A.D. 1300 and A.D. 1400 (Greenman, 1927). Coll. 1965 and subm. by C. E. Cieland, Mus., Michigan State Eniv. Comment (CEC): date is reasonable for this occupation.

\section{M-1772r. Loyd site, Illinois (revised)}

$665 \pm 100$

Charred corn kernels from Loyd site $\left(38^{\circ} 44^{\prime} 35^{\prime \prime} \mathrm{N}\right.$ Lat, 90 $0^{\prime} 15^{\prime \prime}$ II Long), Madison Co., Illinois. Sample from Feature 48, a Mississippian storage/refuse pit. Sample previously reported as A.D. 1520, which was "substantially later than expected," (Mich XI). Subsequently a sample (charred corn cob fragments) from Feature 2 was submitted by Ill. State Mus. to Isotopes, Inc., for determination of $\mathrm{C}^{12} / \mathrm{C}^{13}$ ratio to check possibility that isotopic fractionation in corn had contributed to the anomalous findings obtained. When suspicion confirmed (Hall, 1967), a sample of corn kernels from Feature 48 was also submitted for $\mathrm{C}^{12} / \mathrm{C}^{13}$ analysis.

Revised (late A.D. 1285 was obtained by adding 235 yr to previously determined B.P. age to offset anomalous enrichment of $\mathrm{C}^{1+}$ in the corn during its life. Degree of enrichment from fractionation cannot be cal- 
culated directly in laboratory when age of sample is variable, so it was closely approximated by doubling degree of enrichment of $\mathrm{C}^{13}$ in sample as determined by means of isotope ratio mass spectrometer. Results of the $\mathrm{C}^{12} / \mathrm{C}^{13}$ analysis of Feature 48 corn kernels were reported by Isotopes, Inc., as a $\delta \mathrm{C}^{13}$ value of -10.9 per mil relative to Pee Dee belemnite (P.D.B.) standard established by Harmon Craig for carbon isotope ratio measurements. From this a $\delta \mathrm{C}^{13}$ of +14.7 per mil $(+1.47 \%)$ from oak standard was calculated and then doubled to provide figure of $2.94 \%$ for estimated $\mathrm{C}^{1+}$ enrichment of sample in life. Because each $1 \%$ of $\mathrm{C}^{14}$ enrichment reduces apparent age by about $80 \mathrm{yr}$, the originally calculated date was corrected by addling $2.94 \times 80$ yr to age of sample expressed in radiocarbon years B.P.

Coll. 1963 by P. J. Munson; subm. by Robert L. Hall, Ill. State Mus. Comment (RLH): resulting clate of A.D. $1285 \pm 100$ satisfactorily close to A.D. 115()-1250 range originally estimated for sample.

\section{M-1775. Hayes Arboretum Mound, Indiana A.D. 1330}

$620 \pm 100$

Charred wood from Hayes Arboretum Mound $\left(39^{\circ} 50^{\prime} \mathrm{N}\right.$ Lat, $84^{\circ}$ $51^{\prime}$ W Long), Wayne Co., Indiana. From one post hole of about 25 in SE $1 / 4$ of Square 50W5. In center of approx. $40 \mathrm{ft}$ sq. outline was crematorium. Coll. 1965 by J. M. Heilman; subm. by J. B. Cope, Joseph Noore Mus., Richmond, Indiana. Comment (JMH): although there were no diagnostic artifacts in mound, it should be about same age as adjacent waterworks mound which had biconcave gorgets, copper beads, mica, and thin, fine cordmarked pottery. Mound was probably of Hopewell origin; date is too late.

\section{M-1776. Calumet Ancient Pit, Michigan}

$1280 \pm 140$

Charcoal from Calumet Ancient Pit $\left(47^{\circ} 14^{\prime} 30^{\prime \prime}\right.$ N Lat, $88^{\circ} 26^{\prime} 30^{\prime \prime}$ W Long), $1200 \mathrm{ft}$ SW of SE cornerpost of Sec. 14, T56N, R33W, Houghton Co., Michigan. Sample from $10 \mathrm{ft}$ depth. Coll. 1865 by E. J. Hulbert; subm. by J. B. Griffin (1966), Mus. of Anthropol., Univ. of Michigan. Comment (JBG): date indicates that Late Woodland Indians were actively collecting native copper.

\section{Jasper Newman site series, Illinois}

Charcoal from Jasper Newman site $\left(39^{\circ} 32^{\prime} 30^{\prime \prime} \mathrm{N}\right.$ Lat, $88^{\circ} 42^{\prime} 15^{\prime \prime}$ W Long), T12N, R4E, NW 1/4 SW 1/4 Sec. 25, Moultrie Co., Illinois. Coll. 1964 and 1965 and subm. by W. M. Cardner, Dept of Anthropol., Univ. of Illinois, Urbana.

\section{M-1786. Jasper Newman site, Feature 1 A.D. 1330}

$620 \pm 110$

Charcoal (R23) from Feature 1, S30W25, $1.4 \mathrm{ft}$ below surface, associated with Middle Mississippian wall trench house and Cahokia CordMarked pottery with grit-tempered component. 
M-1787. Jasper Newman site, Feature 6

Charcoal (R24) from Feature 6, N5W5, $1.4 \mathrm{ft}$ below surface, associated with Middle Mississippian refuse pit and same Cahokia CordMarked pottery.

M-1788. Jasper Newman site, Feature 1 $570 \pm 110$

Ticklle Miat (R25) from Feature 1, S20W25-S20W30, associated with Marked pottery.

M-1789. Jasper Newman site, Feature 2

$2000 \pm 140$

(R26) from Feature 2, S16WT, $2.45 \mathrm{ft}$ below surface in a Niddle Woodland pit, associated with Havana ceramics.

M-1790. Jasper Newman site, Feature $33 \quad 2030 \pm 140$

Charcoal (R29) from Feature 33, S37E25-S37E26.5, 2.56 to 2.7 it below surface, in Middle Woodland pit, associated only with Havana ceramics. More than a dozen charred corn cobs from same level subm. to Dr. Hugh Cutler for study.

General Comment (WMG): both Mississippian and Hopewcllian dates seem satisfactory.

\section{M-1795. Burnt Bluff, Michigan}

$1575 \pm 130$

Wood from Burnt Bluff (45 $41^{\prime}$ N Lat, $86^{\circ} 44^{\prime}$ W Long), T38N, R20W, SW 1/4 NE 1/4 Sec. 24, Delta Co., Michigan. From Feature 1, N1 E1, 2.7 ft below datum. Sample from 3 woolen poles supporting birchbark mat, upon which was an infant burial. Coll. 1965 and subm. by D. E. Janzen for Mus. of Anthropol., Univ. of Michigan. Comment (DEJ): clate is much earlier than anticipated; material falls within range of North Bay II as defined by Mason (1966).

\section{M-1808. Spring Creek site, Michigan \\ $1880 \pm 140$}

Charcoal from Spring Creek site (20 Mu 3), (130 16' N Lat, 86º $07^{\prime}$ W Long), Muskegon (io., Michigan. From firepit in Square $55 \mathrm{~N} 30 \mathrm{E}$, at 20 in. below surface. Site very homogeneous and yielded Early Late Woodland culture (Fitting, 1965; Michigan III). Coll. 1956 by George Davis; subm. by J. E. Fitting. Comment (JEF): date is much earlier than expected and ca. 900 yr too early to fit cultural material from site.

\section{Shannon site series, Wisconsin}

Charcoal from Shannon site $\left(45^{\circ} 50^{\prime} 55^{\prime \prime} \mathrm{N}\right.$ Lat, $89^{\circ} 33^{\prime} 24^{\prime \prime} \mathrm{W}$ Long), Wisconsin. From a charred $\log$ found in Test Pit 4. Log dates base of relatively long sequence of fossil pollen. Artifactual materials alone are inadequate in placing cultural phase within Late Woodland period 
in area. Coll. 1965 by E. Benchley and D. Knight; subm. by R. J. Salzer, Logan Mus., Beloit, Wisconsin.

\section{M-1810. Shannon site log, outer layer}

Charcoal from charred $\log$ from Test Pit 4, at bottom of Mound fill I at depth of 2.45 to $2.85 \mathrm{ft}$.

\section{M-1811. Shannon site log, outer layer}

$850 \pm 120$

Charcoal from same charred $\log$ from Test Pit 4, at bottom of Mound fill $\mathrm{I}$ at depth of $2.75 \mathrm{ft}$ at center of $\mathrm{E}$ wall.

General Comment (RJS): samples were submitted with hope of providing loundation for pollen sequence. Palynologist and assays agree with cach other and with my estimate based on associated cultural material that an Effigy mound occupation was responsible for mound construction.

\section{Juntunen site series, Michigan}

Ciharcoal from Juntunen site $(20 \mathrm{Mk} 1)\left(45^{\circ} 49^{\prime} \mathrm{N}\right.$ Lat, $84^{\circ} 35^{\prime} \mathrm{W}$ I.ong), Mackinac Co., Michigan. Site is described by McPherron (1967). Present series may serve as check on previous series (M-1140 - M-1142, Michigan VI; Crane and Griffin, 1961). Coll. 1961 and subm. by Alan McPherron, Univ. of Pittsburgh.

\section{M-1815. Juntunen site, Occupation A}

$870 \pm 120$

Sample from Square 700-120, lowest level (below Feature 23), about 6 ft below surface. Comment (AMcP): although some distance from M-1142, both were from lowest occupation zone with similar artifacts, and were expected to be about the same age, yet M-1815 appars to be 200 vr too young. Neither sample received pretreatment.

\section{M-1816. Juntunen site, Occupation B}

Sample from Square 870-140, between square sheets 8 and 9. Comment (AMCP): sample came from levels firmly placed stratigraphically between levels of Samples M-1142 and M-1141; it was hoped estimate would fall between dates for those samples, but appears slightly too young.

\section{M-1817. Juntunen site, Occupation D}

$$
820 \pm 120
$$

Sample from Square 870-140, between square sheets 4 and 5. Comment (AMcP): as a check on M-1140, the only previous date for Occupation D or Bois Blanc phase, this estimate is reasonable.

\section{M-1843. Fort Wayne Mound, Michigan}

$$
1200 \pm 120
$$

Fragments of human bone from Fort Wayne Mound (20 WN 1) (42 $17^{\prime} 40^{\prime \prime} \mathrm{N}$ Lat, $83^{\circ} 7^{\prime} 20^{\prime \prime} \mathrm{W}$ Long), Wayne Co., Michigan. From Burial 14 and associated Wayne Cross-hatched vessel. Should date earliest burial group in mound (Fitting, 1965; Halsey, n.d.) Coll. 1945 by Carl 
Holmquist; subm. by J. E. Fitting. Comment (JEF): date is acceptable and coincides with other SE Michigan dates for early Late Woodland.

\section{Samel's Woods, Skegemog Point series, Michigan}

Wood charcoal from Samel's Woods, Skegemog Point (44 $18^{\prime} 21^{\prime \prime}$ N Lat, $85^{\circ} 20^{\prime} 54^{\prime \prime} \mathrm{W}$ Long), T27N, R8W, NE $1 \frac{1}{4} \mathrm{SW} 1 / 4$, Sec. 24 , Whitewater Twp., Grand Traverse Co., Michigan. Coll. 1966 and subm. by C. E. Cleland.

M-1863. Samel's Woods, Skegemeg Point, A.v. 1685

$865 \pm 120$

\section{N130, E10}

A.D. $1210 \pm 120 \mathrm{~N}$

Wood charcoal from Feature 3, small hearth in E wall below surface of Level 3, Square N130-E10.

M-1864. Samel's Woods, Skegemog Point, A.d. 1320

$$
630 \pm 110
$$

\section{N200, W100}

A.D. $1310 \pm 110 \mathrm{~N}$

Wood charcoal from N200, W100, Level 1 (0 to 0.3 ft depth).

$$
\begin{array}{lll}
1100 \pm 120 \\
\text { M-1865. Samel's Woods, Skegemog Point, } & \begin{array}{l}
\text { A.D. } 850 \\
\text { A.D. } 950 \pm 120 \mathrm{~N} \\
\text { A.D. } 900 \pm 129 \mathrm{~N}
\end{array} \\
& \text { N120, W10 }
\end{array}
$$

Wood charcoal from Feature 2, hearth in Square N120, W10. General Comment (CEC): this series of dates indicate occupation between about A.D. 900 and A.D. 1300. Dates agree with those of similar Late Woodland occupations in NW Michigan.

\section{M-1868. Samel's Field, Skegemog Point, $\quad 1440 \pm 120$ Michigan \\ A.D. 510}

Wood charcoal from Samel's Field, Skegemog Point $\left(44^{\circ} 49^{\prime} 24^{\prime \prime} \mathrm{N}\right.$ Lat, $85^{\circ} 21^{\prime} 5^{\prime \prime} \mathrm{W}$ Long), T28N, R9W, NW 1/4 SW 1/4, Sec. 13, Whitewater Twp., Grand Traverse Co., Michigan. From Feature 5-66, in Square N280-W681. Coll. 1966 and subm. by C. E. Cieland. Comment (CEC): site is on post-Algonquin pre-Nipissing beach probably formed ca. 8000 в.c. Iancelate projectile points excavated from beach inclicate approximately same age for human occupation.$$
\text { A.D. } 1610
$$$$
\text { A.D. } 1495 \pm 100 \mathrm{~N}
$$$$
\text { A.D. } 1600 \pm 100 \mathrm{~N}
$$

Charcoal from Fauver site $\left(44^{\circ} 56^{\prime} 18^{\prime \prime} \mathrm{N}\right.$ Lat, $85^{\circ} 16^{\prime} 54^{\prime \prime} \mathrm{W}$ Long), T29N, R8W. NW 1/4 SE 1/4, Sec. 4, Helena Twp., Antrim Co., Michigan. Sample from hearth in W wall of Square N50-W50, Level 3 (0.6 to $0.9 \mathrm{ft}$ depth). Coll. 1966 and subm. by C. E. Cleland. Comment (CEC): typological similarities to ceramics and projectile point styles from Skegemog Point site, dated as late as A.D. $1310 \pm 110$. Fauver site inclicates A.D. $1495 \pm 100$ is probably most accurate date of occupation.
}$$
340 \pm 100
$$ 


\section{M-1867. Schuler site, Michigan}

Charcoal from the Schuler site $\left(44^{\circ} 50^{\prime} 12^{\prime \prime} \mathrm{N}\right.$ Lat, $85^{\circ} 21^{\prime} 46^{\prime \prime} \mathrm{W}$ Long), T28N, R8W, NE 1/4 SW 1/4, Sec. 12, Whitewater Twp., Antrim Co., Michigan. Sample from hearth in $\mathrm{N}$ wall of Square 4, Level $3(0.6$ to $0.9 \mathrm{ft}$ (lepth). Coll. 1966 and subm. by C. E. Cleland. Comment (CEC): normalized date of A.D. 1040 \pm 120 for Schuler site agrees with 2 earliest dates from Skegemog Point site (M-1863 and M-1865). Similarities between artifacts from the 2 sites also indicate contemporary occupation.

\section{M-1869. Miami Fort site (33 Ha 62), Ohio}

$1680 \pm 130$

Charred wood fragments from Miami Fort site (33 Ha 62) $\left(39^{\circ} 7^{\prime}\right.$ $15^{\prime \prime} \mathrm{N}$ Lat, $84^{\circ} 48^{\prime} 50^{\prime \prime} \mathrm{W}$ Long), Hamilton Co., Ohio. At base of delensive earthwork (Unit E) $\mathrm{N}$ side of site, 3.0 to $5.2 \mathrm{ft}$ below irregular surface of Unit E. Coll. from thin (about $0.1 \mathrm{ft}$ ) stratum of charred material below zone of red burned wall fill (1.2 to 3.0 ft thick). Charred material was resting on original sub-embankment surface. Should be contemporary with construction of similar earthwork fortifications in central Ohio Valley, such as Fort Ancient and Fort Hill. Coll. 1966 by D. E. Kidd and F. W. Fischer; subm. by F. W. Fischer, Univ. of Michigan. Comment (FWF): somewhat earlier than expected but reasonable.

\section{M-1889. Graham Cave, Missouri}

$9290 \pm 300$

Charcoal from Graham Cave (23 MT 2) (38 54' N Lat, $91^{\circ} 34^{\prime} \mathrm{W}$ Long), Montgomery Co., Missouri. Sample from natural level (ash lens ranging from $21 / 2$ to $31 / 4$ in. thick) on original floor of cave, $661 / 2$ to $69 \mathrm{in}$. below present surface deposit in Square $135 \mathrm{~N}, 85 \mathrm{~W}$. Associated with fragments of modified fluted blades, modified fluted blades reworked into drills, scrapers, blades, utilized flakes, rubbed hematite, small eyedneedles of bone, and an antler tang (Chapman, 1957; Logan, 1952). Coll. 1966 by W. E. Klippel; subm. by W. R. Wood, Univ. of Missouri. Comment (WEK): date perlectly respectable and compares favorably with other sites in SE with Dalton zones.

\section{M-1899. Flycatcher site, Missouri}

$560 \pm 100$

Charcoal from Flycatcher site (23 (LE 153) $\left(37^{\circ} 35^{\prime} 48^{\prime \prime} \mathrm{N}\right.$ Lat, $93^{\circ}$ $46^{\prime} 28^{\prime \prime}$ W Long), Cedar Co., Missouri. Site is a single component. Sample from fill of Feature 61, a pit in Square 640NW530, originating at depth of occupational level. Coll. 1966 and subm. by W. R. Wood. Comment (WRW): seems eminently reasonable.

M-1900. Rodgers Shelter, Missouri

$8030 \pm 300$ 6080 B.c.

Charcoal from Rodgers Shelter (23 BE 125) (38 $5^{\circ} 30^{\prime \prime} \mathrm{N}$ Lat, $93^{\circ}$ $20^{\prime} 40^{\prime \prime}$ W Long), Benton Co., Missouri. Sample found in shallow, basin- 
shaped, charcoal-filled pit $12 \mathrm{ft}$ below surface in Stratum 1. No artifacts were associated with it, but it can be placed beween a Dalton component (below) and a level containing principally Rice-Lobed projectile points (above). Coll. 1966 by R. B. McMillan; subm. by W. R. Wood. Comment (RBM and WRW): date is satisfactory since it falls in the expected period of post-Dalton/pre-Rice-Lobed interval and corroborates earlier clate from same stratum and approximately same depth.

\section{M-1902. Umber Point Mound, Missouri}

$950 \pm 120$

Charcoal from Umber Point Mound (23 CiE 148) (37 $37^{\prime} 12^{\prime \prime} \mathrm{N}$ Lat, $93^{\circ} 46^{\prime} 10^{\prime \prime} \mathrm{W}$ Long), Ciedar Co., Missouri. Found among bones of cremated Burial 4, in Square 50NW60, on approx. level of former ground level. Apparently tumulus is Late Woodland or Early Mississippi period burial mound (Wood, 1966). Coll. 1966 by R. E. Pangborn; subm. by W. R. Wood. Comment (WRW): seems reasonable.

\section{Blain Village site series, Ohio}

Charcoal and portion of burned $\log$ from pits in Blain Village site $\left(39^{\circ} 18^{\prime} 49^{\prime \prime} \times\right.$ Lat, $82^{\circ} 56^{\prime} 16^{\prime \prime} \mathrm{W}$ Long), Ross Co., Ohio. Site is affiliated with Baum focus of Fort Ancient aspect and samples should date from this time. Coll. 1966 by O. H. Prufer and J. E. Blank; subm. by O. H. Prufer, Univ. of Massachusetts. Comment (OHP): date of M-1910 too late for cultural complex, but M-1911 seems correct.

\section{M-1910. Blain Village site, Pit 6}

Portion of burned $\log$ from Pit $6,+66^{\prime \prime}-12^{\prime \prime}$.

\section{M-1911. Blain Village site, Pit 1}

$490 \pm 100$

A.D. 1460

A.D. $1440 \mathrm{~N}$

$760 \pm 100$

Charcoal from Pit 1, Unit II; sample from 36" level.

\section{M-1928. Graham Cave, Missouri}

$9470 \pm 400$

7520 B.C.

Charcoal from Graham Cave (23 MT 2) (38 54' N Lat, $91^{\circ} 34^{\prime} \mathrm{W}$ Long), Montgomery Co., Missouri. Found on natural level on original floor $(661 / 2$ to 69 in. below present surface of deposit in Square $130 \mathrm{~N}$, $85 \mathrm{~W})$. Cultural materials within natural level include fragments of modified fluted blades, modified fluted blades reworked into drills, scrapers, blades, utilized flakes, rubbed hematite, small eyed-needles of bone, and antler tangs (Chapman, 1957; Logan, 1952). Coll. 1966 and subm. by W. R. Wood. Comment (WRW): clate seems reliable.

\section{Blackwell Cave series, Missouri}

Charcoal from Blackwell Cave (23 HI 172) $\left(37^{\circ} 58^{\prime} 2^{\prime \prime} \mathrm{N}\right.$ Lat, $93^{\circ}$ $19^{\prime} 5^{\prime \prime}$ W Long), E bank of Pomme de Terre River, Hickory Co., Missouri. Coll. 1966 by C. R. Falk; subm. by W. R. Wood. Comment 
(WRW): both dates seem consistent with stratigraphic position and associated material.

\section{M-1929. Blackwell Cave, Feature 10}

$2680 \pm 150$

Charcoal from Feature 10, small hearth-charcoal-filled pit. Associated were small mammal bone, shell fragments, and lithic waste. Should date a Late Archaic or Early Woodland context (Wood, 1961).

\section{M-1930. Blackwell Cave, Feature 1 \\ A.D. 1230}

$720 \pm 110$

Charcoal from Feature 1, large basin-shaped hearth. Many animal bones and shells were in pit along with variety of lithic waste and tool fragments. Small arrowpoints and grit-tempered sherds closely associated (Wood, 1961).

\section{A.D. 1040}

$910 \pm 120$

A.D. $1110 \mathbf{N}$, or

A.D. $1180 \mathrm{~N}$, or

\section{M-1931. Loftin site, Missouri}

A.D. $1210 \mathbf{N}$

Charcoal from Loltin site (23 SN 42) $\left(36^{\circ} 38^{\prime} \mathrm{N}\right.$ Lat, $93^{\circ} 28^{\prime} \mathrm{W}$ Long), Stone Co., Missouri, from floor level of House 1, Square 30NE35. Shell-tempered pottery (plain) found on floor of this 4-post house, probably built in a pit, with postlined entryway. This is a Mississippian site with strong Caddloan overtones (Wood and Marshall, 1958). Cioll. 1957 and subm. by W. R. Wood. Comment (WRW); normalized dates are within range of variation for Mississippian site in area.

$$
\begin{aligned}
& 860 \pm 100 \\
& \text { A.D. } 1090 \\
& \text { A.D. } 1210 \mathrm{~N}
\end{aligned}
$$

\section{M-1932. Sorter Mound, Missouri}

Seeds, largely carbonized maize kernels, from Sorter Mound (23 CE 150) $\left(37^{\circ} 36^{\prime} 2^{\prime \prime} \mathrm{N}\right.$ Lat, $93^{\circ} 45^{\prime} 43^{\prime \prime} \mathrm{W}$ Long), Cedar Co., Missouri. Sample taken from SW corner of Square 60NW50, at depth of 18 in., near bedrock, just $S$ of Burials 3 and 6 . Associated cultural materials (limestone tempered pottery, “Cahokia points") suggest Late Woodland-Early Mississippian period. Coll. 1965 and subm. by W. R. Wood. Comment (WRW): since sample consisted of charred maize kernels almost exclusively, A.D. $1210 \mathrm{~N}$ probably too late.

\section{Lower Mississippi Valley and Southeast U.S.}

M-1486. Cherry Valley mound group, Mound 2, $\quad \mathbf{8 5 0} \pm 110$ Arkansas

Charred wood from Cherry Valley Mound 2 (11 N 17) $\left(\begin{array}{ll}35^{\circ} & 26^{\prime} \mathrm{N}\end{array}\right.$ Lat, $90^{\circ} 45^{\prime} \mathrm{W}$ Long), NE 1/4 Sec. 2, T9N, R3E, Mitchell Twp., Cross Co., Arkansas. From entrance of burned house under Mound 2. Site yielded new culture complex for NE Arkansas and is important because of re- 
markable resemblance of pottery vessels to those of Cahokia in Illinois. Cherry Valley may represent splinter group created by population increase at Ciahokia (Michigan V). Coll. 1958 and subm. by Gregory Perino. Comment (GP): clate better than first runs (M-917, $1250 \pm 120 ; \mathrm{M}-918$, $1030 \pm 150$; Michigan V and VI), which made this earliest Mississippi site known. Charcoal from same source used in both samples.

\section{M-1501. Warner Smith Place, Arkansas}

$520 \pm 100$

Charred wood from the Warner Smith Place $\left(35^{\circ} 21^{\prime} 20^{\prime \prime} \mathrm{N}\right.$ Lat, $90^{\circ}$ $9^{\prime} 28^{\prime \prime}$ W Long), Crittenden Co., Arkansas. From excavation of portion of house in uppermost of 2 levels. Small Walls-Pecan Point site overlaying smaller Early Mississippi site on small ridge near slough and levee, probably on Mississippi River when occupied. Coll. 1958 and subm. by Gregory Perino. Comment (GP): seems close to actual date for site. Conforms to dates of similar sites such as Banks and Barton Ranch.

\section{Spiro site series, Oklahoma}

Charcoal, shell, and wood from the Spiro site $\left(35^{\circ} 18^{\prime} 45^{\prime \prime} \mathrm{N}\right.$ Lat, $94^{\circ} 34^{\prime} \mathrm{W}$ Long), Le Flore Co., Oklahoma. (Campbell, 1961; Orr, 1956, 1952; Brown, 1966). Coll. 1937 by F. E. Clements; subm. by J. A. Brown, Univ. of Oklahoma, Norman.

\section{M-1661. Spiro site, Craig Mound B-10}

Charcoal from Craig Mound B-10, main mound unit containing group burial. Grave contains numerous artifacts including Bird-on-man effigy pipe, 2 wooden face masks, 11 long flint blades, and copper discs.

\section{M-1662. Spiro site, Craig Mound B-62 A.D. 1400}

Conch shell from Craig Mound B-62, part of large collection of material heaped on a litter burial (B-62) illustrated by Orr (1946). Burial is one of many deposited on floor of Great Mortuary beneath main mound unit designated Stage B. Part of mortuary described as famous hollow "central chamber" (Hamilton, 1952). Conch shell from same provenience was dated as M-815 at $580 \pm 150$ (Michigan VIII).

\section{M-1663. Spiro site, Craig Mound B-62}

A.D. 1270

$680 \pm 100$

Cedar pole section (Juniperus virginiana) from Craig Mound B-62, part of litter containing burial and grave goods of B-62, including sample M-1662. Should provide check on conch shell from this grave and contemporary graves (M-1665).

\section{M-1664. Spiro site, Craig Mound B-108-16}

$400 \pm 100$

Organic material, probably comprised of cedar bark cordage, and fabric of animal and vegetal fibers. Sample poorly preserved mass of similar fabrics found in "central chamber." From deposit placed on 
Stage B2 of Great Mortuary. Material contemporary and stratigraphically equivalent to samples M-1662 and M-1663. Should provide internal check upon dates from B-62 and M-1665.

\section{M-1665. Spiro site, Craig Mound B-155-1 \\ $490 \pm 120$}

Conch shell from large deposit of decorated and undecorated conch shell from Stage B2 (Great Mortuary). Date should be same as M-1662.

\section{M-1667. Spiro site, Brown Mound}

A.D. 1010

$940 \pm 100$

Cedar fragments (Juniperus virginiana) from Brown Mound. Part of wood deposited on flank of Stage D of Mound. Sample not only dates this stage, but also provides lower limit on age of 2 graves sunk into flank of mound and intrusive through last recognizable stage (E). One grave contains wooden bird effigy, group of conch shells arranged in square, brushed surface bottle, and other items.

\section{M-1668. Spiro site, Craig Mound A6-19 A.D. 700}

$1250 \pm 100$

Charcoal from Craig Mound A6-19. From grave located at N edge of main mound unit that produced conch shell containers, jar, and 7 copper repoussé "eagle" plates.

\section{M-1670. Spiro site, Craig Mound A-24-1 A.D. 720}

$1230 \pm 110$

Charcoal from deposit in S edge of main mound unit directly below M-816 (Michigan V). These 2 samples are not tied in stratigraphically with central floor area (Stage B) and could easily belong to earlier part of sequence.

\section{M-1671. Spiro site, Craig Mound $1225 \pm 110$ $\begin{array}{lll}\text { B-162-11 } & \text { A.D. } 725\end{array}$}

Charcoal from Craig Mound B-162-11 in grave overlying Great Mortuary and belonging to period later than main mound Stage B. Ten vessels associated (Bell, 1953), a copper plate, small "Caddoan" pipes, earspools, and other items.

General Comment (JAB): dates from Great Mortuary made on cedar wood, cloth, and marine shell consistent with each other and previous determinations (Ciampbell, 1961). Reruns on same or neighboring materials by Michigan are also consistent; compare M-1662 with M-815 (Michigan VIII) on shell from same grave, and M-1670 with M-816 (Michigan V) on charcoal from stratigraphically superimposed beds. Dates M-1667 and M-1661 acceptable, but others from Craig mound are not. M-1668 and M-1671 dates are inconsistent with stratigraphy and cultural context; probably represent charcoal from early occupation (Brown, 1966).

\section{Breckenridge Shelter series, Arkansas}

Vegetal material and charcoal from Breckenridge Shelter (3 CR 2) $\left(36^{\circ} 24^{\prime} 40^{\prime \prime} \mathrm{N}\right.$ Lat, $93^{\circ} 50^{\prime} 30^{\prime \prime} \mathrm{W}$ Long), Carroll Co., Arkansas. Site is 
large bluff shelter on upper White River in W-central Ozarks, excavated in 1922 by Mus. of the Amer. Indian (Harrington, 1960), and in 1932, 1960-62 by Univ. of Arkansas Mus. (Thomas, 1962; Wood, 1963). Deposits containing cultural materials extend $3.5 \mathrm{~m}$. deep; these range from Early Archaic projectile points near bottom to late prehistoric materials, including perishable remains, at top. No datable organic remains recovered from lower levels. Site formerly named "Pine Hollow" shelter.

M-1687. Breckenridge Shelter, Burial PH-276

A.D. 1130

$820 \pm 110$

Portion of cradle found with infant burial, $35 \mathrm{~cm}$. below surface. Cradle and associated materials described in detail (Dellinger, 1936); no projectile points or pottery directly associated. Coll. 1932 for S. C. Dellinger; subm. by C. R. McGimsey, III, Univ. of Arkansas Mus.

M-1688. Breckenridge Shelter, hearth $\mathbf{0} \pm \mathbf{1 0 0}$

Charcoal from hearth found 40 to $60 \mathrm{~cm}$. below surface. Nearby material included shell-tempered pottery, contracting-stem dart points, and arrowpoints. Cioll. 1961 by W. R. Wood; subm. by C. R. McGimsey, III.

M-1689. Breckenridge Shelter, shelter deposits

A.D. 1810

$140 \pm 100$

Charcoal from 20 to $40 \mathrm{~cm}$. below ground surface, found with contracting-stem dart points, arrowpoints, and shell-tempered pottery. Coll. 1961 by W. R. Wood; subm. by C. R. McGimsey, III.

\section{M-1690. Breckenridge Shelter, shelter} deposits

$520 \pm 100$

A.D. 1430

Charcoal from 40 to $60 \mathrm{~cm}$. below ground surface, found with contracting-stem and corner-notched dart points, arrowpoints, and shelltempered pottery. Coll. 1961 by W. R. Wood; subm. by C. R. McGimsey, III.

\section{M-1691. Breckenridge Shelter, hearth}

$1590 \pm 130$

Charcoal from hearth found at depth 68 to $83 \mathrm{~cm}$. below surface. Dart points in same level included corner-notched and contracting-stem specimens. Coll. 1962 by R. A. Thomas; subm. by C. R. McGimsey, III. General Comment (CRMcG): M-1688 was apparently contaminated, as it was expected to provicle assay comparable to M-1690. M-1689-M-1691 are stratigraphically consistent and provide acceptable ages for Late Archaic and Mississippian-related components at site, although earher portion of one-sigma range for M-1689 is probably closer to true age.

\section{M-1694. Red Rock Shelter, Arkansas}

$1990 \pm 140$

Charcoal from Red Rock Shelter (3 CR 70) $\left(36^{\circ} 22^{\prime} 40^{\prime \prime}\right.$ N Lat, $93^{\circ}$ $49^{\prime} 45^{\prime \prime}$ W Long), Carroll Co., Arkansas. Site is bluff shelter on tributary 
of White River in W-central Ozarks of NW Arkansas. Deposits in shelter were quite shallow, and charcoal was recovered from firepit 15 to $22 \mathrm{~cm}$. below ground surface in Trench 7 . Most of stone tool assemblage comparable to that found in lower levels of Breckenridge Shelter (3 CR 2) (Thomas 1962; Wood 1963), and includes lanceolate and side-notched dart points regarded typologically as Early Archaic (McGimsey, 1963). Several corner-notched and contracting-stem dart points and an arrowpoint also were recovered and represent later brief occupations. Coll. 1963 and subm. by C. R. McGimsey, III. Comment (CRMcG): sample apparently relates to Late Archaic occupation represented by cornernotched and contracting-stem dart points.

\section{M-1697. Brady site, Arkansas \\ Charcoal from Brady site (3 WA 22) (36 $6^{\circ} 8^{\prime} \mathrm{N}$ Lat, 94" 3' $30^{\circ} \mathrm{W}$}

$560 \pm 110$ Long), Washington Co., Arkansas, one of very few pottery-bearing open sites (as contrasted with bluff shelters) on upper White River in NW Arkansas. Charred wood and nut hulls taken from 40 to $50 \mathrm{~cm}$. level of Pit 15 , in association with heavy accumulation of cobbles and rock fragments, flaked ovate choppers of soft ferruginous rock, corner-notched and contracting-stem dart points, ovate and corner-notched arrowpoints, and other stone artifacts and a few clay-tempered sherds. Sherds closely fit description of pottery types Williams Plain and Williams Incised, found at late components of Archaic Fourche Maline focus. Coll. 1962 by J. A. Scholtz; subm. by C. R. McGimsey, III. Comment (CRMcG): site seems to have been occupied by group or groups of single cultural complex with very late Archaic affiliation. Age of sample seems too recent even for terminal Archaic date unless, as is strongly suspected, this cultural stage persisted in $\mathrm{W}$ Ozarks until relatively late in prehistoric period.

\section{M-1701. Red Bluff Shelter, Arkansas}

$1580 \pm 130$

Human bone from Red Bluff Shelter (3 BE 11) (36 $21^{\prime} 40^{\prime \prime} \mathrm{N}$ Lat, $93^{\circ} 54^{\prime} 30^{\prime \prime} \mathrm{W}$ Long), Benton Co., Ark. Site is large bluff shelter on upper White River, NW Ark., excavated in 1922 by Mus. of the Amer. Indian (Harrington, 1960) and in 1932 by Univ. of Ark. Mus. Skeletal material was from Burial RB-65, recorded as flexed showing evidence of burning, found $75 \mathrm{~cm}$. below surface. Associated were a barbed corner-notched dart point, a scraper, shell beads, and a mussel shell. No pottery found, but shelter did contain basketry, cordage, and a kernel of corn, as well as corner-notched and contracting-stem dart points and other chipped stone tools. Coll. 1932 for S. C. Dellinger; subm. by C. R. McGimsey, III. Comment (CRMCG): date of sample and associated materials suggests Late Archaic occupation. Corn kernel probably reflects later occupation.

\section{Eden Bluff series, Arkansas}

Grass, other vegetal material, and human bone from Eden Bluff (3 BE 6) (36 $16^{\prime} 20^{\prime \prime}$ N Lat, $94^{\circ} 4^{\prime} 15^{\prime \prime}$ W Long), Benton Co., Ark. Site is 
very large bluff shelter on upper White River in NW Ark. Field notebooks for site list nearly 1800 artifacts and at least 16 burials, 9 showing evidence of burning. In addition to materials mentioned below, artifacts include both grit- and shell-tempered pottery, corner-notched dart points, objects of wood and cane, bone tools, and remains of corn, sunflower, and beans. Site easily accessible and thoroughly vandalized. Coll. 1932 for S. C. Dellinger; subm. by C. R. McGimsey, III.

\section{M-1702. Eden Bluff, Burial E-19}

$\mathbf{8 7 0} \pm \mathbf{1 1 0}$

Grass associated with flexed burial found $76 \mathrm{~cm}$. (2'6") below surface, in Tr. 261 and 262. Associated material included shell tools and ornaments, contracting-stem dart points, chipped stone knives, a fragment of basketry, hazelnuts, gourd and squash fragments, hackberry seeds, fish scales, plum seeds, grape stems, and a robe made of hide, string, and feathers.

\section{M-1703A. Eden Bluff, Burial E-19}

Same as M-1702; textile and plant remains.

$$
\begin{array}{r}
1320 \\
\text { A.D. } 630
\end{array}
$$

\section{M-1703. Eden Bluff, Burial E-315}

$1750 \pm 130$

Portion of flexed, somewhat charred skeleton found $84 \mathrm{~cm}$. below surface, associated with side-notched, straight-stem, and contractingstem dart points, chipped stone knives, mussel shells, and 2 hammerstones. Comment (CRMCG): range of dates entirely reasonable.

\section{Ricart Shelter series, Arkansas}

Human bone from Ricart Shelter (3 WA 5) (36 $4^{\prime} 36^{\prime \prime}$ N Lat, $94^{\circ}$ $20^{\prime} 40^{\prime \prime} \mathrm{W}$ Long), Washington Co., Arkansas. A bluff shelter in W Ozarks on Illinois River, which clrains SW to Arkansas River. Other materials inclucle basketry, corn cobs, clay-tempered potsherds, contracting-stem and corner-notched dart points, and other stone tools. Coll. 1933 for S. C. Dellinger; subm. by C. R. McGimsey, III.

\section{M-1704. Ricart Shelter, Burial RI-43}

A.D. 1670

$$
280 \pm 100
$$

Skeletal material from flexed burial $79 \mathrm{~cm}$. below surface; skull was absent. Associated artifacts included shell-tempered potsherds, bone awls, a grooved stone, and mussel shells.

\section{M-1705. Ricart Shelter, Burial RI-73}

$$
720 \pm 110
$$

Left tibia from flexed burial $90 \mathrm{~cm}$. below surface; skull was absent. Associated material included bone and shell artifacts and a shell-tempered potsherd.

General Comment (CRMCG): associated shell-tempered pottery and similar burial pattern suggest long period of occupation at site by groups of Mississippian-related complex. Assay for Sample M-1705 tends to cor- 
roborate seemingly early date for shell-tempered pottery at Brown Bluff site (3 WA 10) (Sample M-1711).

\section{Pine Creek Shelter series, Arkansas}

Human bone from Pine Creek Shelter (3 MA 2) (36 $12^{\prime} \mathrm{N}$ Lat, $93^{\circ}$ $40^{\prime}$ W Long), Madison Co., Arkansas, a bluff shelter on small tributary of the Kings River, a major tributary of White River in NW Arkansas. Additional materials found at site include both shell- and clay-tempered potsherds. Cioll. 1932 for S. C. Dellinger; subm. by C. R. McGimsey, III.

\section{M-1706. Pine Creek Shelter, Burial PC-1 A.D. 935}

$1015 \pm 120$

Skeletal material from flexed burial $45 \mathrm{~cm}$. below surface. Associated artifacts included a contracting-stem and a barbed straight-stem dart point, a basket, and bone tools.

\section{M-1707. Pine Creek Shelter, Burial PC-19 A.D. 1320}

$630 \pm 110$

Skeletal material from burial $15 \mathrm{~cm}$. below ground surface; burial position uncertain. Associated artifacts included 2 contracting-stem and 2 corner-notched dart points, worked mussel shell, a mano, and a milling stone.

General Comment (CRMcG): absence of associated pottery makes interpretation difficult. Sample M-1706 could relate to either Late Archaic or early ceramic complex occupation, while Sample M-1707 almost certainly relates to ceramic occupation. Ages of samples are stratigraphically consistent, although there is no way of knowing at what level Burial PC-1 originated. Burial PC-19 suggests shelter burials in this area and period may have been extremely shallow.

\section{M-1708. Rock House Shelter, Arkansas}

$600 \pm 110$

Plant remains from Rock House Shelter (3 MR 35) $\left(36^{\circ} 6^{\prime} \mathrm{N}\right.$ Lat, $92^{\circ} 34^{\prime} 15^{\prime \prime} \mathrm{W}$ Long), Marion Co., Arkansas. Site is bluff shelter on Panther Creek, tributary of Buffalo River in central Ozarks. Sample was taken from cache of charred plant material (RP-127) including corncobs, acorns, and hickory nuts, $42 \mathrm{~cm}$. below surface. A limestone slab milling stone was over cache. Other artifacts included corner-notched, basalnotched, straight-stem, and contracting-stem dart points, other chipped stone tools, mussel shells, bone tools, animal bone and hide, cordage and basketry, and shell-tempered potsherds; flexed burials also were present. Coll. 1934 for S. C. Dellinger; subm. by C. R. McGimsey, III. Comment (CRMcG): only dated sample from NW Arkansas found in direct association with corn, although a number of other sites represented by this general series of $\mathrm{C}^{14}$ assays also contained corncobs or corn kernels.

\section{Brown Bluff series, Arkansas}

Plant material from Brown Bluff (3 WA 10) $\left(35^{\circ} 52^{\prime} \mathrm{N}\right.$ Lat, $94^{\circ} 10^{\prime}$ $30^{\prime \prime}$ W Long), Washington Co., Arkansas. Site is bluff shelter on small 
tributary of W Fork of White River in SW Ozarks. In addition to material listed below, cultural remains found at site included 3 flexed burials, clay-tempered potsherds, mummified dog remains, corncobs, basketry, a moccasin, and shell, bone, and stone artifacts, including a corner-notched clart point. Coll. 1932 for S. C. Dellinger; subm. by C. R. McGimsey, III.

\section{M-1711. Brown Bluff, Cache BR-78}

$840 \pm 110$

Portions of cache of sunflower seeds, acorns, walnuts, hickory nuts, and leaves covered with fragment of basketry. Top of cache found $45 \mathrm{~cm}$. below surface. Nearby material included shell-tempered potsherds.

\section{M-1711A. Brown Bluff, Burial BR-123a A.D. 1160}

$790 \pm 110$

Portion of burned gourd rattle; fragments of "fabric," and deer antler tine associated with cremated, flexed burial, $32 \mathrm{~cm}$. below surface. (ieneral Comment (CRMCG): somewhat surprising to find shell-tempered pottery in this area as early as M-1711 seems to suggest. Assays are stratigraphically inconsistent, but difference in depth of samples was slight and there is widle overlap in $1 \sigma$ ranges of the 2 assays.

\section{M-1713. Key Marco, Florida}

$280 \pm 100$

Fiber Lrom Key Marco $\left(25^{\circ} 58^{\prime} 15^{\prime \prime}\right.$ N Lat, $81^{\circ} 43^{\prime} 45^{\prime \prime} \mathrm{W}$ Long), Collier Cio., Florida. From bundle of finished corlage (Cushing, 1896). Coll. 1896 and 1897 during Pepper-Hearst Expedition by F. H. Cushing; subm. by J. A. Ford, Florida State Mus., Gainesville. Comment (JAF): Cushing collection from Key Marco does not contain ceramics which are usual basis for precise dating in SE. Decorative motifs in preserved wood specimens suggest relationships to Middle Mississippi and imply "Southern Cult." No European trade goods were found. Date in Ifith or 17th century is not unlikely.

\section{Robinson site series, Tennessee}

Charcoal and human bone from the Robinson site $\left(36^{\circ} 15^{\prime} \mathrm{N}\right.$ Lat, $85^{\circ} 53^{\prime}$ W I Long), Smith Cio., Tennessee. Samples from Archaic "shellmound." Cioll. 1963 and subm. by D. F. Morse, Idaho State Univ.

\section{M-1797. Rohinson site, Burial 5}

$3200 \pm 160$

Charcoal from fill of Burial 5 which was placed in reluse or storage pit.

$\begin{array}{ll}2970 & \pm 150\end{array}$

Mohinson site, Features 31 and $32 \quad 1020$ в.c.

Charcoal from both leatures 31 and 32 , storage pits.

M-1799. Robinson site, Feature 35

$2970 \pm 150$

Charcoal from Feature 35, postmold belonging to house located midray in stratigraphy. 
M-1800. Robinson site, Feature 43

Charcoal from Feature 49, refuse pit.

M-1801. Robinson site, Feature 46

$2530 \pm 150$

Charcoal from Feature 46, cooking pit.

580 в.c.

M-1802. Robinson site, Feature 69

$2830 \pm 130$

Charcoal from Feature 69, cooking pit.

880 B.c.

M-1803. Robinson site, Feature 69

$2450 \pm 140$

Charcoal from Feature 69, cooking pit.

M-1805. Robinson site, Burial 56

$2630 \pm 130$

680 B.C.

Human bone from Burial 56, skeleton sitting in circular pit associated with $15 \mathrm{~cm}$. long partially decomposed sandal sole (?), conch shell gorget, 2 mussel shell spoons, and 20 conch shell disc beads. Right femur, female, 20 yrs.

M-1806. Rohinson site, Burial $\mathbf{5 8}$

$2410 \pm 200$

Human bone from Burial 58, skeleton sitting in circular pit associated with 31 artifacts including 7 Motley-type projectile points. Right femur, female, 22 yrs.

General Comment (DFM): clates are acceptable although later than expected. Specimens M-1802 and 1803 are from hearth and might have been closer in age. Skeletal material probably younger than true age.

\section{U. S. Great Plains}

\section{Arp Village site series, South Dakota}

Charcoal from Arp site $(39 \mathrm{Br} 101),\left(43^{\circ} 35^{\prime} \mathrm{N}\right.$ Lat, 99 $20^{\prime} \mathrm{W}$ Long), Brule Co., So. Dakota, with both late Woodland and Over focus occupations. Ciorn cobs and cache pits were present, but no house remains (Hurt, 1961). Coll. by students 1961; subm. by W. R. Hurt, Indiana Univ., Bloomington, Incliana.

M-1411. Arp site, Extension 3

Charcoal from Extension 3, 70 in. depth.

M-1413. Arp site, Test 7, Feature 1

Charcoal from Test 7 , Feature 1, 37 in. depth.

M-1414. Arp site, Extension 5

Charcoal from Extension 5, Feature 9, 42 in. depth.

\section{A.D. 1160}

$790 \pm 100$

\section{A.D. 1020}

$930 \pm 110$

$1200 \pm 110$ 
M-1415. Arp site, Extension 31, Unit I

$1530 \pm 120$ pit base.

Charcoal from Extension 31, Unit I, cache pit, Feature 10, from

\section{M-1417. Arp site, Extension 7}

$1290 \pm 120$

Charcoal from Extension 7 , cache pit 3 .

A.D. 760

General Comment (WRH): dates for Late Woodland tradition at Arp site range from A.D. 420 to A.D. 810 . However, 210 yr separate M-1414, 1415, and 1417, assigned to Late Woodland, from M-1411 and M-1413, assigned to Over locus, yet no discernible stratigraphic separation was visible.

\section{M-1421. Arp site mound, South Dakota}

$1170 \pm 200$

Wood from mound $\left(43^{\circ} 35^{\prime} \mathrm{N}\right.$ Lat, $90^{\circ} 20^{\prime} \mathrm{W}$ Long), Brule Co., So. Dakota. Found $200 \mathrm{~m}$. $\mathrm{N}$ of Arp site in mound partially destroyed by wave action. Several secondary burials were removed from wood-covered central burial pit at depth $4.75 \mathrm{ft}$. Coll. 1960 by J. W. Rauth; subm. by W. R. Hurt. Comment (WRH): corresponds to range of dates for Woodland component at Arp site. However, no diagnostic artifacts found to draw close associations. Date fits into Plains Woodland tradition for area.

\section{M-1422. Wolf Creek site, South Dakota}

$75 \pm 100$

Wood from Wolf Creek site (39 HT-201), (43 $28^{\prime} \mathrm{N}$ Lat, $97^{\circ} 30^{\prime}$ W Long), Hutchinson Cio., So. Dakota. Found in Mound 2, Feature 5 above 12 secondlary and primary burials with Woodland sherds. Should be roughly contemporary with Sherman Park mounds, (14 date: A.D. 375 (Hurt, 1963) (Isotopes Inc., I-744 not pub.). Coll. 1962 by Robert Gant; subm. by W. R. Hurt. Comment (WRH): modern.

\section{Northeastern U.S., Canada}

\section{M-1712. Sandwich West Ossuary, Ontario, Canada \\ $100 \pm 100$ A.D. 1850}

Charred human bone from Sandwich W Ossuary $\left(42^{\circ} 14^{\prime} \mathrm{N}\right.$ Lat, $83^{\circ}$ 6' W Long), Sandwich W Twp., Essex Co., Ontario, Canada, recovered with cremation and flesh burials. Ossuary contains burials with perforated crania, Macomb Linear and Springwells Net Impressed vessels (Fitting, 1965). Coll. 1954 by J. DeVisscher; subm. by J. E. Fitting. Comment (JEF): date is at least 500 yr later than expected. Doubtful that Younge tradition survived this late, some $150 \mathrm{yr}$ after founding of Detroit across the river.

\section{St. Albans site series ( $46 \mathrm{KA} 27$ ), West Virginia}

Charcoal from St. Albans site (38 $23^{\prime} \mathrm{N}$ Lat, $81^{\circ} 48^{\prime} \mathrm{W}$ Long), West Virginia, in town of St. Albans between U.S. Route 60 and Kanawha River next to West Virginia State Road Commission Substation (Price 
et al., 1964; Broyles, 1966). Coll. 1964 and 1965 by B. J. Broyles; subm. by E. V. McMichael, State of W. Virginia, Geological and Economic Survey.

$7700 \pm 450$

M-1818. St. Albans site, Zone 6 5750 B.C.

Charcoal (cat. no. 71) from Zone 6, Feature 16, 9.5 ft below surface. Le (roy type projectile points associated. Same level dated $6900 \pm 100$ в.c. (Yale-1539).

\section{M-1820. St. Albans site, Zone 11}

$8820 \pm 300$

6870 B.C.

Charcoal (cat. no. 73) from Zone 11, 6 ft below surface. St. Albans type projectile points associated.

\section{M-1821. St. Albans site, Zone 12}

$8830 \pm 700$

St. Albans projectile points associated.

\section{M-1824. St. Allans site, Zone 20}

$8.520 \pm 300$

Ciharcoal (cat. no. 77) from Zone 20, Feature 80, 10 li below surlace. Kirk corner-notched projectile points, small variety, associated. Same level dated 6965 \pm 100 B.c. (Yale-1538).

\section{M-1827. St. Albans site, Zone 36}

$9850 \pm 500$

Charcoal (cat. no. 80) from Zone 36 , Feature 110, 15 to 16 ft below prescnt surface. Two corner-notched, possibly Kirk, projectile points associated and 1 side-notched. Small sample, but run 96 instead of 48 hrs.

General Comment (EVM): satisfactory results although somewhat dillerent from Yale's assays.

\section{Murad Mound series, St. Allans, West Virginia}

Charcoal and wood from Murad Mound (38 29' N Lat, $81^{\circ} 47^{\prime} \mathrm{W}^{\prime}$ I.ong), between old U. S. Route 60 and railroad on E edge of St. Albans. W. Virginia (McMichael, 1963). Coll. 1969 by O. L. Mairs: subm. by E. V. McMichael.

M-1829. Murasl Mound, Tomb 1

Charcoal from under Tomb I, shallow fircpit or crematory basin.

M-1830. Murad Mound, Toml, 2

$2050 \pm 149$

Wood from Tomb $2 \log$ on $\mathrm{N}$ side.

Gronal Comment (LVM): samples earlier than expected, if they date this Hoperell mound. 
M-1832. Buffalo site (46 PU 31), West Virginia

$1850 \pm 120$

Charcoal from Buffalo site (38 $36^{\circ} \mathrm{N}$ Lat, $82^{\circ} \mathrm{W}$ Long), between Route 35 and Kanawha River, $1.5 \mathrm{mi}$. S of Buffalo village, Putnam Co., W. Virginia. From Feature 2, large firepit or oven in Block 50W20. Subdivision (i-4, at 42 in. depth. Well sealed-olf layer of Archaic with 1.0 to 1.5 li flood deposits between Archaic and Fort Ancient (McMichael, 1966). Coll. 1965 and subm. by E. V. MoMichael. Comment (EVMI): anything later than 1000 B.c. is highly unlikely in view of cultural behavior during counting period.

\section{M-1934. Buffalo site, West Virginia}

$3870+250$

1920 B.C.

Charcoal from Buffalo site ( $\left.16 \mathrm{P}^{\mathrm{P}} 3 \mathrm{31}\right)\left(38^{\circ} 36^{\prime} \mathrm{X}\right.$ Lat, $82 \circ \mathrm{W}$ Long). Putnam Cio., W. Virginia, between Route 35 and Kanawha River, 1.5 mi. S of Buffalo village. Sample taken from Feature 2, a large Late Archaic firepit or oven in Block 50W20, Sublivision (i-4, at depth of 31 in. Coll. 1964 and subm. by E. V. Mc.Michael. Comment (EVM): pertains to sealedoff Archaic horizon covered by 1 to 5 ft of alluvium and distinct from more common Fort Ancient occupations at this site. Projectile points include medium-sized corner-notched type and contracted-stemmed type. Apparently, surface was open long enough that transition is readily seen between the 2 types. Date sems to indicate very Late Archaic placement. (Sample came from same pit as M-1892, which produced a date much too late. A.n. $100 \pm 120$.)

\section{Mount Carbon Village series, West Virginia}

Charcoal from Mount Cimbon Village (46 FA 7) $\left(38^{\circ} 8^{\prime} \times\right.$ Lat, $81^{\circ}$ $1 \tau^{\prime}$ W Long), between Route 61 and Kanawha River just upstream from mouth of Armstrong Cireek, Wr. Virginia (McMichael, 1962). Coll. 1962 and subm. by E. V. McMichael.

\section{M-1834. Mount Carbon Village, Feature 131 \\ $880 \pm 100$}

Charcoal from Feature 131. Square $210 \mathrm{~S}$, $180 \mathrm{E}$, shallow orate pit containing typical Armstrong Hoperiell clay-tempered pottery.

\section{M-1835. Mount Carbon Village, Feature 90 A.D. 820}

Charcoal from Feature 90, Square $180 \mathrm{E}, 190 \mathrm{~S}$. Circular cooking pit with very late Armstrong pottery. transitional to Buck Garden pottery. Coneral Comment (EV.M): date somewhat later than expected for M-1834 and will be rerun: perhaps satisfactory for M-18.95.

\section{M-1834. Mount Carbon Village, West Virginia}

Charcoal from Mount (arbon Village $(46$ FA 7$)\left(38^{\circ} 8^{\prime} \times\right.$ Lat, 81 $17^{\prime}$ W Long), Fayette Co.. W. Virginia. Sample from Feature 131 (Square 2) $10 \mathrm{~S}, 180 \mathrm{E}$,) a shallow ovate pit containing typical Amstrong Hoperell 
clay-tempered pottery (McMichael, 1962). Coll. 1962 and subm. by E. V. McMichael. Comment (JBG): rerun of small sample; first run published above.

\section{M-1933. Mount Carbon Village, West Virginia A.D. 120}

$1830 \pm 140$

Charcoal from Mount Ciarbon Village (46 FA 7) $\left(38^{\circ} 8^{\prime} \mathrm{N} \mathrm{Lat}^{\circ} 81^{\circ}\right.$ $17^{\prime}$ W Long), Fayette Co., W. Virginia, between Route 61 and Kanawha River just upstream from mouth of Armstrong Creek. Sample taken from Feature 136, an Armstrong culture pit, Square $180 \mathrm{E}, 170 \mathrm{~S}$, at depth of 30 in. Coll. 1962 and subm. by E. V. McMichael. Comment (EVM): this dates Armstrong Hopewell pit, containing typical Armstrong series pottery sherds. Dating more satisfactory than previous runs on M-1834 above in that it is regarded as local equivalent of Hopewellian climax stage.

\section{M-1898. Mohr site, Bainloridge, Pennsylvania}

Charcoal from Mohr site $\left(40^{\circ} 6^{\prime} \mathrm{N}\right.$ Lat, $76^{\circ} 40^{\prime} \mathrm{W}$ Long), Bainbridge, Pennsylvania. Sample from base of midden pit; should clate associated Shenk's Ferry pottery and burial complex. Since this seems to be single component late prehistoric site (apart from Archaic materials in topsoil) it will provide date for Shenk's Ferry component. Comment (JBG): too recent lor even late prehistoric Shenk's Ferry occupation.

\section{Sheep Rock Shelter series, Pennsylvania}

Charcoal and organic material from Sheep Rock Shelter (36 HU 1) (78 ${ }^{\circ} \mathrm{N}$ Lat, $40^{\circ} 15^{\prime} \mathrm{W}$ Long), Huntingdon Cio., Pennsylvania. Coll. 1959 and 1960 by J. Witthoft and F. Kinsey; subm. by J. W. Michels, Pennsylvania State Univ.

\section{M-1903. Sheep Rock Shelter, Level 2c}

$$
260 \pm 100
$$

Charcoal from Level 2c on stratigraphic profile for pit; 42 to $45 \mathrm{in}$. b.cl. Level $\mathrm{B}$ on $\mathrm{S} 10$ master profile. Comment (JWM): clate probably closer to earlier part of S.D. range (1590-1640); probably dates Susquehannock occupation.

\section{M-1904. Sheep Rock Shelter, Level 3}

$$
490 \pm 100
$$

Charcoal from Zone $4 \mathrm{~b}$ on stratigraphic profile for pit; 60 to $64 \mathrm{in}$. b.d. Level C on S10 master profile; Level C on W5 master profile; Level 3 on profile key. Comment (JWM): date can probably be attributed to Owasco or Shenk's Ferry occupation.

\section{M-1905. Sheep Rock Shelter, Level 2}

Charcoal from Level $\mathbf{F}$ on stratigraphic profile for the pit; 74.5 in. b.d. Level B on $\mathrm{S} 5$ master profile; Level 2 on profile key. Comment (JWM): date probably closer to earlier part of S.D. range (1500-1600), may possibly clate Shenk's Ferry or Susquehannock occupation. 
M-1906. Sheep Rock Shelter, Level 5

$4300 \pm 180$

Charcoal from Level B on stratigraphic profile for pit; 88.5 to 96 in. b.d. I Level E on S5 master profile; Level D on W10 master profile; Level 5 on profile key. Comment (JWM): dates Late Archaic component.

\section{M-1907. Sheep Rock Shelter, Level 6}

$3800 \pm 180$

Charcoal from 98.5 to $105 \mathrm{in.}$ b.cl. Level $\mathrm{H}$ on $\mathrm{S} 15$ master profile; Level E on W10 master profile; Level 6 on profile key. Coll. from welldefined fire pit. Comment (JWM): date is anomalous in terms of stratigraphic provenience. Further analysis of specific stratigraphic setting of sample is scheduled for summer 1967 .

\section{M-1908. Sheep Rock Shelter, Level 9}

$7050 \pm 250$

Organic material in sample from Level $\mathrm{K}_{1}$ on stratigraphic profile for pit: 134 to $138 \mathrm{in.} \mathrm{b.d.} \mathrm{Level} 12$ on $\mathrm{S} 10$ master profile; Level 9 on profile key. Comment (JWM): probably terminal Early Archaic date, based on stratigraphic relation to diagnostic Early Archaic artifacts.

\section{M-1909. Sheep Rock Shelter, Level 10}

$8870 \pm 320$

Organic material in sample from Feature 3; 155 to 167.5 in. b.d. Levels J and $\mathrm{K}$ on master profile; Level $\mathrm{M}$ on $\mathrm{S} 10$ master profile. Comment (JWM): Sample has feature association and underlies Kirk CornerNotched points. It is in stratigraphic association with a bifacially-ground celt fragment.

\section{IVestern United States}

\section{M-1434. Lucy site, New Mexico}

$14,300 \pm 650$

12,750 в.C.

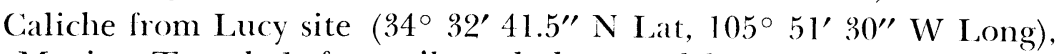
New Mexico, Trench 1, from silt and clay pond bottoms which overlay Sandia material found in situ. Caliche formed after deposit of layers on pond bottom. Origins of carbon in caliche is not clearly understood. Coll. 1958 and subm. by William Roosa, Univ. of Waterloo, Ontario, Canada. Comment (WR): date of clay formation on pond bottom should be close to that of Valders advance.

\section{M-1754. Jemez Cave, New Mexico}

$470 \pm 100$

Pieces of tanned deerskin robes and fiber and feather cordage from feather robe from Jemez Cave ( $35^{\circ} 48^{\prime} \mathrm{N}$ Lat, $106^{\circ} 36^{\prime} \mathrm{W}$ Long), 2 mi. N of Jemez Springs, Sandoval Co., New Mexico. Sample associated with dessicated infant burial as wrappings in Section IX, Square F-5, at 4 to $5 \mathrm{ft}$ depth, only burial in large cave. Date will apply to body, burial rrappings, 3 associated ears of "Chapalote" corn, and ceremonial water jar with skin cover. Coll. 1934 by local resident and acquired by the Univ. of New Mexico (Alexander and Reiter, 1935; subm. by V. H. Jones, 
Mus. of Anthropol., Univ. of Michigan. Comment ( VHJ): date later than anticipated, judging by associated corn type, apparent depth within site, etc. No serious obstacles to acceptance, but a little uncomfortable. Materials may have been treated with organic preservative; possibly a factor in lateness.

$$
\begin{gathered}
840 \pm 100 \\
\text { A.D. } 1110 \\
740 \pm 100 \mathrm{~N} \\
\text { A.D. } 1210 \mathrm{~N}
\end{gathered}
$$

M-1643. Two Kiva site, Arizona

Wood from the Two Kiva site, (35. 14' $15^{\prime \prime} \mathrm{N}$ Lat, $111^{\circ} 22^{\prime} 10^{\prime \prime} \mathrm{W}$ Long), about 25 mi. NE of Flagstaff, Arisona, from I21, N, RloL, Section 6. From roof beam of small Sinagua Pueblo. Cioll. 1964 and subm. by J. C. McGregor, Univ. of Illinois, Urbana. Comment (JBG): sample obtained by J. B. Griffin because of tree ring date, A.p. 1161 to 1183 . Radio(arbon clate comparable to more accurate tree ring age assessment.

\section{M-1672. Marble Canyon, Arizona}

$1180 \pm 110$

Wood (Populus) from Marble Cianyon (36 29' N Iat, $111^{\circ} 51^{\prime} \mathrm{W}$ Long), elev. $3125 \mathrm{ft}$ on Ciolorato River at Mile 43.1 below U.S.C.S. gauging station at Lees Ferry, Arizona. Wood has many characteristics of $P$. angustifolia. Fibril angles clearly visible in S.2 layer of cell wall, produced undoubtedly by long weathering cycles (written comm., Glenn Voohries, Northern Arizona Univ.). Sample from man-made wooden structure (Arizona site (::9:27) spanning crevice on possible cliff-sicle trail $300 \mathrm{lt}$ above river. No cultural association. Coll. 1963 and subm. by R. C. Euler, Prescott College, Prescott, Arizona. Comment (RCE): tentative thesis is that structure was constructed by prehistoric Pueblo Indians as part of cross-canyon trail, but other archaeological sites in vicinity date from A.1). $100(0)$ to 1150.

\section{M-1720. Drag Strip site, Arizona}

$$
1260 \pm 110
$$

Wood charcoal (Sample 1) from Drag Strip site $\left(33^{\circ} 30^{\prime} \mathrm{N}\right.$ Lat, $111^{\circ}$ 45' W Long), Arizona, from Mound 1, Square M18 in ash pit, 5l to $5.1 \mathrm{in.}$ (lecp. Sealed with pure Snaketown style pottery. Only Snaketown and Gila Butte styles found in mound. An early Hohokam site, should date Snaketown style pottery in Salt River Valley (Gladwin et al., 1937). Coll. 1964 by Dan Opfenring; subm. by J. C. Ives, Ft. L ew is College, Durango, Colorado. Comment (JCI): date seems to agree with archaeological lacts.

M-1836. U-10-2 (ASU), Arizona

$1410 \pm 120$ A.D. 540

Wood charcoal from U-10-2 (ASU) (33 $28^{\prime} \mathrm{N}$ Lat, $111^{\circ} 46^{\prime} \mathrm{W}$ Long). T2N, R6W, SE 1/4 NW 1/4 Sec. 27, Maricopa Cio., Arizona. From Square $5,32 \mathrm{in}$. below datum, $20 \mathrm{in}$. below surlace. A pure Vahki phase site of the Hohokam sequence (Gladwin et al., 1937). Coll. 1965 by D. J. Oplenring; subm. by J. C. Ives. Comment (JCI): clate seems to agree with archaeological evidence. 


\section{T-16-19 (ASU) series, Arizona}

Wood charcoal from 'T-16-19 (ASU) $\left(33^{\circ} 12^{\prime} 45^{\prime \prime} \mathrm{N}\right.$ Lat, $112^{\circ} 5^{\prime} \mathrm{W}$ Long), T2S, R3W, SE 1/4 NW 1/4 Sec. 32, Maricopa Cio., Arizona on lands of Cila River Indian Community. With exception of M-1840, samples from Houses of Vahki phase of Hohokam sequence (Gladwin et al., 1937). Coll. 1966 by D. J. Oplenring; subm. by J. C. Ives.

\section{M-1837. T-16-19 (ASU), House 1}

$1500 \pm 120$

Wood charcoal from House 1, Square 11, 48 in. below datum, 36 in. below surface. From burned post in situ. Sample should date very early prototype Hohokam house. May clate late in Vahki phase.

\section{M-1838. T-16-19 (ASU), House 2}

$$
1520 \pm 120
$$

Wood charcoal from House 2, Square 21, 34 in. below datum, 22 in. below surface. From rool fall of house which is atypical and appears to be shaman's hut. Vahki phase.

\section{M-1839. T-16-19 (ASU), House 3}

$1180 \pm 120$

Wood charcoal from House 9, Line A, 93 to 44 in. below datum. Fire pit associated in nearly square house with wall trench.

\section{M-1840. T-16-19 (ASU), Line 2}

$1180 \pm 110$

Wood charcoal from Line 2, Square 14, 39 to 45 in. below datum, 21 to $39 \mathrm{in}$. below surface. From cooking area in $5 \mathrm{ft}$ diam. pit. EstrellaSreetwater phase association; should date beginning of Swcetwater phase of Hohokam sequence.

\section{M-1842. T-16-19 (ASU), Line 1}

$$
1300 \pm 120
$$

Wood charcoal from Line 1, Squares 1 and 2, 30 to 42 in. below datum in pit. Sherds of Vahki phase of Hohokam sequence in association (Ciladwin et al., 1937).

General Comment (JCI): dates for M-1837 and M-1838 agree with archaeological evidence and with M-1836 also from Vahki phase. M-1839 cannot be Vahki phase; field notes and pottery find spots are being re-examined. Post-Vahki sherds were in wall trench but only Vahki pottery came from floor itself. M-1840 is from stratified locality and wood sample is definitely older than Swectwater phase. M-1842 is from poor find spot. Some later material could have been mixed with Vahki phase rubbish; sample was not taken from a definite leature.

\section{M-1841. U-9-25 (ASU), Arizona}

$1180 \pm 120$

Wood charcoal lrom U-9-25 (ASU) $\left(33^{\circ} 29^{\prime} \mathrm{N}\right.$ Lat, $111^{\circ} 49^{\prime} \mathrm{W}$ Long), T2N, R6W, Sec. 19, Maricopa Co., Arizona. From I ine 40, Sec. ccr-aaa, 15 in. below surface, fire pit cut into caliche with fire-cracked rocks. Vahki phase of Hohokam sequence (Gladwin et al., 1937). Coll. 
1966 by Thomas Ciaperton; subm. by J. C. Ives. Comment (JCiI): clate does not seem to apply to Vahki phase but site is very shallow and single Snaketown-style sherd was found near hearth.

\section{Lamb Spring site series, Colorado}

Bone from Lamb Spring site $\left(39^{\circ} 30^{\prime} 66^{\prime \prime} \mathrm{N}\right.$ Lat, $105^{\circ} 3^{\prime} 52^{\prime \prime} \mathrm{W}$ Long), near Littleton, Colorado. This bone bed yielded mammoth, camel, and bison bones. Coll. 1962 and subm. by W. R. Wedel, Smithsonian Inst.

\section{M-1463. Lamb Spring site, Sample 1}

$8870 \pm \mathbf{3 5 0}$

Bison bone (probably B. occidentalis) from bed of disarticulated bones on $\mathrm{N}$ side of spring. Depth 40 to 42 in. Similar deposit on s side of spring believed contemporaneous, associated with Eden midsection and possibly with variant Scottsbluff.

\section{M-1464. Lamb Spring site, Sample 2 \\ $13,140+1000$}

Mammoth bone from spring sand $\mathrm{N}$ of spring vent and stratigraphically below bison bone bed yield Sample 1. Depth 96 to 108 in. Only possible human association was worked camel toe bone found below pile of mammoth bone about 11 ft underground. Cimment (WRW): M-1463 date is 1000 yr earlier than date of bison bone from same level by Smithsonian lab. Bone bed is very likely on Eden-Scottsbluff level from archaeological evidence. Mammoth bone was associated with worked camel toe bone, the only eviclence of human occupation.

\section{M-1542. Mount Albion site, Colorado}

$970 \pm 100$

Charcoal from Pit 1 at Mt. Albion site $\left(40^{\circ} 2^{\prime} 30^{\prime \prime} \mathrm{N}\right.$ Iat, $105^{\circ} 30^{\prime}$ 30" W Long), Boulder Co., Colorado. Sample (id. as spruce by U.S. Forest Products Lab.) from surface of charcoal layer beneath $11 / 2$ ft of loose (lebris in center of rock-walled pit at 12,000 ft alt. on crest of ridge extending E from summit of Mt. Albion. Site is complex of low rock walls and circular, rock-walled pits above timberline in Colorado Front Range that suggests either a game drive or fortified position. Projectile points coll. from charcoal layer are small and corner-notched; most have serrated edges. Site younger than most recent period of patterned-ground activity on this ridgetop. Coll. 1969 and subm. by J. B. Benedict, Inst. Arctic and Alpine Research, Nederland, Colorado. Comment (JBB): date falls within expected limits of 1250 to 950 yr b.P. Charcoal from another pit in same complex dated at $670 \pm 150$ B.P. (SI-301).

\section{Piney Creek series, Wyoming}

Charcoal from Piney Creek (48 JO $311-312)$, (443 $31^{\prime} \mathrm{N}$ Lat, $106^{\circ}-17^{\prime}$ W Long), Wyoming. Expected to give chronological position of Late Prehistoric or Early Historic buffalo hunting group using ceramics suggestive of Mandan-Hidatsa tradition. Cioll. 1964-65, and subm. by Cieorge Frison, 612 Obie Sue, Worland, Wyoming. 
M-1747. Piney Creek, Stone Circle 9

A.D. 1610

Charcoal from stone circle No. 9, shallow hearth $0.2 \mathrm{ft}$ below surface in mat of buffalo grass roots.

M-1748. Piney Creek, Stone Circle 12

$370 \pm 100$

Charcoal from stone circle No. 12, small pit containing potsherds and 2 small side-notched projectile points, 0.2 to $0.7 \mathrm{ft}$ below surface with some grass root intrusion.

M-1749. Piney Creek

A.D. 1850

$100 \pm 100$ surface.

Charred bone (Bison bison) from concentration 0.7 to $1.0 \mathrm{ft}$ below

\section{M-1750. Piney Creek, Firepit 1}

$120 \pm 100$

Charcoal from Firepit 1, $2.2 \mathrm{ft}$ below present surface in stone-filled pit with side-notched projectile point and unburned bone (Bison bison).

\section{M-1751. Piney Creek, Firepit 2}

A.D. 1875

$75 \pm 100$

Charcoal from Firepit 2, $2.5 \mathrm{ft}$ below surface in stone-filled pit with grooved maul, side-notched projectile point, and consiclerable tree root intrusion.

\section{M-1752. Piney Creek, Firepit 3}

$$
50 \pm 100
$$

Charcoal from Firepit 3, shallow stone-filled pit with intense tree root intrusion.

General Comment (GF): A.D. 1610 (M-1747) and A.D. 1580 (M-1748) from stone circles in $48 \mathrm{JO} 311$ seem to clate closely first appearance of buffalo hunters in area with ceramics suggesting affiliation with Mandan-Hidatsa tradition. A.D. 1850 (M-1749), A.D. 1830 (M-1750), A.D. 1875 (M-1751), and A.D. $1900(\mathrm{M}-1752)$ are much too late for $48 \mathrm{JO} 312$ since archaeological evidence suggests the 2 sites are closely related and represent pre-horse occupation. Possible contamination of samples as result of proximity to surface and penetration of carbonized roots.

\section{Big Goose Creek series, Wyoming}

Charcoal from Big Goose Creek (48 SH 313) (444 $44^{\prime} \mathrm{N}$ Lat, $107^{\circ} 9^{\prime}$ IV Long), near Sheridan, Wyoming. Site is about $5 \mathrm{ft}$ above Big Goose Creek. Soil is heavy gumbo and continuously damp. Irrigation water from upper stream terrace has flooded site for $80 \mathrm{yr}$, but good drainage prevents swamp. Dates should give chronological position of late prehistoric or early historic buffalo-hunting group using ceramics that suggest affiliation with Mandan-Hidatsa tradition. Coll. 1966 and subm. by George Frison. 
M-1859. Big Goose Creek, 1.25 ft depth

$450 \pm 110$

Charcoal from shallow, stone-filled hearth $1.25 \mathrm{ft}$ below surface and $.25 \mathrm{ft}$ below level of occupation. Considerable live root penetration from trees and perennial weeds.

\section{M-1860. Big Goose Creek, 3.35 ft depth A.D. 1420}

$530 \pm 110$

Charcoal from stone-filled hearth $3.35 \mathrm{ft}$ below surface and $1.25 \mathrm{ft}$ below level of occupation. Some root penetration from weeds. General Comment (GF): dates seem early but may be correct.

\section{Saw Mill Canyon series, Idaho}

Soil from Saw Mill Canyon (10 BT 62), (1. 12' 30" N Lat, 1130 2' 30" W Long), Idaho. Coll. 1962 by David Rice; subm. by E. H. Swanson, Idlaho State Univ. Mus., Pocatello.

M-1447. Saw Mill Canyon, Test Pit 4B

$$
1540 \pm 130
$$

Compact dark brown humus with some angular rubble and pea gravel intermixed, from Test Pit $4 \mathrm{~B}$, Level 1 . W face, SW corner $\mathrm{N}, 10$ to $24 \mathrm{~cm} \mathrm{depth}$.

\section{M-1450. Saw Mill Canyon, Test Pit 8 \\ $2230 \pm 140$}

Dark brown soil from Test Pit 8 , E Face Corner, 10 to 15 cm depth.

\section{M-1451. Saw Mill Canyon, Test Pit 8}

$2640 \pm 140$

690 в.C.

Dark brown soil from Test Pit 8, E Face Center, 25 to $30 \mathrm{~cm}$ depth.

\section{M-1452. Saw Mill Canyon, Test Pit 8}

$4380 \pm 200$

Dark brown soil from Test Pit 8, E. Face Center, 40 to $47 \mathrm{~cm} \mathrm{depth.}$

M-1453. Saw Mill Canyon, Test Pit 8

$4780 \pm 200$

2830 B.C.

Dark brown soil from Test Pit 8, E Face Center, 64 to $71 \mathrm{~cm}$ depth.

\section{M-1454. Saw Mill Canyon, Test Pit 8}

$6540 \pm 230$

Dark brown soil from Test Pit 8 , E Face Center, 80 to $100 \mathrm{~cm}$ depth.

\section{M-1455. Saw Mill Canyon, Test Pit 8}

$$
7650 \pm 400
$$

Dark brown clay, some gravel, from Test Pit 8, E Face Center, 95 to $105 \mathrm{~cm}$ depth.

M-1456. Saw Mill Canyon, Test Pit 9

$1980 \pm 130$ ble intermixed from Test Pit 9, Level 1, S Face, 10 to $20 \mathrm{~cm}$ below datum. 
General Comment (EHS): artifacts at site include almost all types known in Birch Creek Valley of $\mathbf{E}$ Idaho and are distributed in soil as function of weight. All points occur in top 15 to $20 \mathrm{~cm}$. Scrapers tend to occur farther down in A horizon; heavier objects, like pestles and milling stones of late vintage, occur at base of humus horizon. Distribution and dates suggest long-term soil stability without marked erosional interval; probably constitutes relic of early post-Pinedale time. Dates also indicate that carbon accumulation relative to time may be measured by vertical soil samples, even though artifacts are redistributed as function of weight. Since site is at $7450 \mathrm{ft}$ alt., lack of marked erosion and even spacing of dates in Test Pit 8 indicate that effective erosional limits of Altithermal in N Rocky Mts. was about $7000 \mathrm{ft}$. Wind erosion and denudation during Altithermal is indicated in same valley below $5100 \mathrm{ft}$. Finally, horizontal distribution of clates inclicates present extent of soil since at least A.D. 410; spring source has not moved in last $1500 \mathrm{yr}$. Uncertain if soils once had greater extent because they were formed on sloping fan surface where sheet erosion could have removed evidence of greater distribution. Present annual precipitation of 10 to 12 in. does not support soil, and preservation depends solely on spring source around which soil has formed. Earliest clate suggests either spring formed then or climatic conclitions at end of Pinedale III glaciation were sufficiently moist on NE slope of Lemhi Range to permit formation of chernozem in number of Birch Creek localities. In either case, there was a period of ground water supply, and soil moisture sufficient to create several such localities in Birch Creek Valley, or to support more soils of this type than today. Earliest date is thus terminus post quem for genesis of relic chernozem-like soil associated with early history of man in E. Idlaho.

\section{M-1853. Wasden site ( 10 BV 30), Idaho}

Unburned bone fragments from Wasclen site $\left(43^{\circ} 36^{\prime} 12^{\prime \prime} \mathrm{N}\right.$ Lat, $112^{\circ} 23^{\prime} 22^{\prime \prime} \mathrm{W}$ Long), Bonneville Co., Idaho. From bison bone bed at base of layer 16, Block E1Z. Majority of bone cores are of Bison bison. One unusually large horn core may be that of Bison antiquus (idl. by M. I. Hopkins, Idaho State Mus.). Bed is enclosed between thick accumulations of finely laminated wind-blown sediments. Sediments below bone bed have been deeply involuted, apparently by perma-frost action. Sample should provide terminal date for period of perma-frost affecting sediments below bed and beginning date for accumulation of sediments overlying becl. Coll. 1966 by K. T. Faler; subm. by Ruth Peereboom, 1247 S. Emerson, Idaho Falls. Comment (B. R. Butler, supervisory ar(haeologist, Idaho State Mus.); site is on Snake River Plain S of Birch Creek Valley; probably dates end of Pinedale Glaciation in $\mathrm{N}$ Rocky $\mathrm{Mts}$. immediately $\mathrm{N}$ of site in valley and end of periglacial conditions on Snake River Plain. Date agrees with one from Bison rockshelter (I-453) in Birch Creek Valley. Only 2 projectile points from bison bone bed at Wasclen site, which appear to be resharpened butts of edge-ground Plano-type points suggesting persistence of Early Big-Game Hunting tra- 
dition on Snake River Plain when Desert Culture tradition was already established in Great Basin.

Mexico, Central and South America

$$
1250 \pm 120
$$

\section{M-1484. Yayaguala, Teotihuacan, Mexico}

Charcoal from Yayaguala $\left(19^{\circ} 41^{\prime} 24^{\prime \prime} \mathrm{N}\right.$ Lat, $96^{\circ} 51^{\prime} 6^{\prime \prime} \mathrm{W}$ Long), Teotihuacan, Mexico. Two separate runs made on same material. Sample found below wall which formed part of E tablero (wall section) of temple $S$ of central patio of Yayaguala. While removing outermost, badly destroyed wall section to expose inner wall structure, $30 \mathrm{~cm}$ layer of calcined earth and carbon fragments was found. Should date when innermost wall was covered by outer wall. Coll. 1961 and subm. by Laurette Sejourne, Apartado Postall 27-506, Mexico D.T. Comment (LS): date seems satisfactory for end of building period at complex.

\section{M-1597. El Tepalcate, Chimalhuacan, Mexico}

$2380 \pm 140$

430 B.C.

Charred wood, oak and pine, from El Tepalcate $\left(19^{\circ} 27^{\prime} \mathrm{N}\right.$ Lat, $98^{\circ}$ 52' W Long), Chimalhuacan, Mexico. From single spot $156 \mathrm{~cm}$. below surface in 1 by $2 \mathrm{~m}$ trench. Site directly linked with origin of urban center of Teotihuacan. Date may aid precise dating of emergence of city and culture. El Tepalcate precedes Teotihuacan, but span is unknown (Noguera, 1943; Millon and Bennyhoff, 1961). Coll. 1963 by Michael West; subm. by William Sanders, Pennsylvania State Univ., University Park, Pennsylvania. Comment (WS): sample is from basal levels of stratigraphic trench. Site was previously excavated by Eduardo Noguera. Analysis from his and our excavations indicates late or terminal pre-classic late: 430 B.c. seems somewhat early but is within probable range. If correct, date suggests some temporal overlap between Chimalhuacan and Ticoman.

\section{Valle del Quijos series, Ecuador}

Charcoal from Valle del Quijos $\left(0^{\circ} 15^{\prime} \mathrm{S}\right.$ Lat, $78^{\circ} \mathrm{W}$ Long), Alto Napo, Oriente Ecuador. Samples provide only dates for area. Coll. 1960 and subm. by P. I. Porras Garcés (1961), Sucursal de Correos No. 5, Quito, Ecuador.

\section{M-1425. Sitio Minda}

$440 \pm 100$

Charcoal from Sitio Minda, Platform A, Pozo 2 at $1 \mathrm{~m}$ depth.

\section{M-1426. Sitio Borja}

Charcoal from Sitio Borja, Platform A, Pozo 1 at $2 \mathrm{~m}$ depth. General Comment (PIPG): samples may have been contaminated by outside water and possibly by moss and lerns that covered walls of well. 
Africa, Europe, Siberia, and Asia

\section{Tenerife Island series, Canary Islands}

Human skin, goatskin, and wood from Tenerife Island $\left(28^{\circ} 30^{\prime} \mathrm{X}\right.$ Lat, $16^{\circ} 15^{\prime} \mathrm{W}$ Long), Canary Islands. (ioll. 1950 and 1955 by Diego Cuscoy, Museo Arqueologico de Tenerife.

\section{M-1054. Hoya Brunco}

$780 \pm 100$

Human skin from La Guancha, from mummy in burial cave. Remnants of several bodies were found. Date will give information of occupation prior to conquest of island.

\section{M-1055. Hoya Brunco}

$910 \pm 110$

A.D. 1040

$930 \pm 110$

Goatskin from La Guancha, from burial cave containing several bodies with remnants of skins in which they were wrapped.

\section{M-1057. La Palmeta}

$1040 \pm 110$

Wood (Pinus canariensus) from Ia Iaguna. Associated with exposed bodies on cave floor with no covering earth. Comment: No comment from Cuscoy has been obtained.

\section{Odry site series, Poland}

Charcoal from the Odry Site 1 (53⒉ $24^{\prime} 33^{\prime \prime} \times$ Lat, $18^{\circ} \mathrm{E}$ Long), Chojnice district, Poland. Coll. 1963 and 1964 by J. Kmiecinski, Univ. of Lodz, Poland; subm. by S. Milisauskas, for Univ. of Michigan Mus. of Anthropol.

\section{M-1857. Odry Site 1, Burial 20}

$1850 \pm 140$

Charcoal from Burial 20 in center of cemetery, $30 \mathrm{~cm}$ below surface, associated with glass beads, a piece of bone comb, burned human bones, a cremated fibula, and a pottery sherd. From Roman period; should date 2nd or 3rd century A.D.

\section{M-1858. Odry Site 1, Burial 101}

$1790 \pm 140$

Charcoal from Burial 101 located in pit in $S$ (younger) part of cemetery, found $85 \mathrm{~cm}$ below surface and associated with burned human bones and buckle of a belt.

General Comment (SM): dates fall within general period.

\section{Bylany series, Czechoslovakia}

Charcoal from Bylany $\left(49^{\circ} 58^{\prime} \mathrm{N}\right.$ Lat, $15^{\circ} 15^{\prime} \mathrm{E}$ Long), Cizechoslovakia, near Kutna Hora about $40 \mathrm{mi}$. E of Prague. Site is Linearkeramik (formerly Damubian I) site. Coll. 1966 and subm. by J. W. Cruber, Temple Univ. 


\section{M-1896. Bylany, Features 2717 and 2718} oven. Sample clates this 2-chambered oven of early phase of Linearkeramik style and associated pottery.

\section{M-1897. Bylany, Feature 2218}

$6320 \pm 230$

Charcoal from Feature 2218 , pit-fill of borrow pit E of oven mouth. It dates borrow pit into which oven was built, and ceramic bowl in oven. a fragment of which lay at same level as sample.

\section{Monastery of St. Catherine series, Egypt}

Wood from the Church of the Transfiguration in the Monastery of St. Catherine $\left(28^{\circ} 44^{\prime} \mathrm{N}\right.$ Lat, $34^{\circ}$ E Long), Sinai Peninsula, Egypt. Coll. 1965 and subm. by G. W. Forsyth, Kelsey Mus., Univ. of Michigan.

\section{M-1812. Church of the Transfiguration gable Modern}

Sample is from a withe which formed armature around circular window with plaster panel decorated with glass fragments. Window was supported in an oculus over altar of fith c. church at St. Catherine's by a wooded chassis which, tested in 1965 as M-1676, was dated as $1500+120$ (Mich. XI).

\section{M-1813. Church of the Transfiguration $1280 \pm 140$ ceiling beam over nave A.D.670}

Beams are the chords of rood trusses. Sample subm. to check results in Mich. XI.

\section{M-1814. Church of the Transfiguration $200 \pm 100$ window A.D. 1750}

Archaeologically and architecturally, window appears to be of 6 th $\mathrm{c}$. construction.

General Comment (GWF): test on M-1813 agrees with those on M-1679, 1675 (Mich. XI) indicating modern ceiling beam M-1677 (Mich. XI) was inserted in 6th c. roof. Such an operation would be extraordinarily difficult, but I see no other solution. M-1814, like M-1812 piece of withe, comes from actual fabric of window, which must have been part of church restoration in early $18 \mathrm{~h}$ c., when window renewal is mentioned in a clocument.

\section{Cayönii Series, Turkey}

Charcoal from Cayönü (38 $14^{\prime} \mathrm{N}$ Lat, $39^{\circ} 3^{\prime} \mathrm{E}$ Long), about $5 \mathrm{kms}$ SW of Ergani, Diyarbakir prov., Turkey. Coll. 1964 by A. J. Jelinek; subm. by R. J. Braidwood for the Joint Prehistoric Project, Istanbul Univ. and the Oriental Inst., Univ. of Chicago. 


\section{M-1610. Cayönï, Unit K6}

Charcoal from Unit K6, Level 4 to 5 .

General Comment (RJB): samples taken from 2 contiguouos 25-sq. m units, at depths well below any trace of surface instrusion. Cayönü assemblage has same general complexion as Jarmo, but differs in detail. No pottery (save for several dozen sherds in turf line to plow depth) in total 150 sq. $m$ of 6 -unit exposure, but artifacts of hot hammered copper were present. Determinations tend to substantiate our confidence in cluster of Jarmo determinations at ca. 6750 в.c. Two Groningen runs were slightly earlier.

\section{Hagia Sophia series, Turkey}

Wood samples from church of St. Sophia, Istanbul $\left(41^{\circ} 16^{\prime \prime} \mathrm{N}\right.$ Lat, $28^{\circ} 59^{\prime} 4^{\prime \prime}$ E Long), Turkey. Church was completed between A.D. 532 and 5.37. has undergone repairs at intervals thereafter, beginning A.D. 563. Coll. 1965 and subm. by R. I. Van Nice, Dumbarton Oaks, Washington, D.C.

\section{M-1942. Sample T-7}

$1160 \pm 120$

Wood sample, sawed-off end of timber projecting from brick masonry above a column (ap) in $\mathrm{S}$ gallery, $\mathrm{E}$ central bay. From structural standpoint it is important to know whether timber was embedded during repair in A.D. 563, or at a much later late.

\section{M-1943. Sample T-8}

$1649 \pm 130$

Wood sample from rough timber connecting masonry above column (ap to $S$ wall, at $E$ side of $S E$ buttress, in $S$ gallery, $E$ bay. Would be useful to determine whether timber belongs to initial construction.

\section{M-1944. Sample T-9}

$160 \pm 100$

Wood sample from thin box with arved ornament surrounding rough, inner timber connecting masonry above column to $\mathrm{S}$ wall at $\mathrm{E}$ side of SE buttress, S gallery, E bay. Essential to know whether this thin, ornamented box surrounding a rough timber is contemporary with it.

\section{M-1945. Sample T-10}

A.D. 1500

A.D. $1450 \mathrm{~N}$

Wood sample from beam spanning arch inserted between original ralls of enclosed room below roof of SE buttress. Timber unquestionably belongs to a late repair, but not clear from factual evidence whether heam and arch were added in 15 th c. or as late as 19 th .

General Comment (RIVN): no comment received from Van Nice. 
M-1686. Igho, Obameri, Ife, Nigeria

Sample came from immediately below earthen bank, probably collapsed wall of inner part of Obameri grove $\left(7^{\circ} 28^{\prime} \mathrm{N}\right.$ Lat, $4^{\circ} 32^{\prime} \mathrm{E}$ Long). Finds included many lragments from different terra cotta sculptures, as if pieces were found cluring farming and building, and brought together in grove. There is also a megalith, standing upside down, with unworked base. A number of shrines housing random assemblages of sculpture fragments are known in Ife. All must be later than Cilassical period of Ife art, when naturalistic sculpture was being made. Classical period still not certain but seems earlier than 14th c. Coll. and subm. 1964 by O. H. Myers, Ibadan, Nigeria. Comment (Frank Willett, Northwestern Univ.): date fits well with knowledge of Ife history, but is isolated; other assays needed to support it.

\section{Engaruka series, Tanzania}

Charcoal from Engaruka $\left(2^{\circ} 59^{\prime} \mathrm{S}\right.$ Lat, $35^{\circ} 58^{\prime} \mathrm{E}$ Long), rift vallev, NE of Ngorongoro, Tanzania (Leakey, 1936; Sassoon, 1966). Coll. 1966 by E. Isai and A. Shonvi; subm. by H. Sassoon, Dar es Salaam, Tanzania.

\section{M-1892. Engaruka, Sample 117}

$470 \pm 110$

Charcoal from terrace of Hillside 2; Hillsicle-terrace A.10, Square C, Level $7(1 \mathrm{~m}, 5 \mathrm{~cm})$. Carbonized sorghum found in lowest levels of (leposit $(1 \mathrm{~m}, 20 \mathrm{~cm})$, which also contained 9 lbs potsherds, 11 lbs animal bone, some shell beads and pendants, 1 glass bead, and several small stone balls.

\section{M-1893. Engaruka, Sample 140}

A.D. 1650

$\mathbf{3 0 0} \pm \mathbf{1 0 0}$

Charcoal from Hillside-terrace A.19 on Hillsicle 1, Square B, Level $6(90 \mathrm{~cm})$. Total depth of deposit $1 \mathrm{~m}, 35 \mathrm{~cm}$. Carbonized sorghum found in Level 6 . Trench also yielded 4 lbs potsherds, 5 lbs animal bone, some shell beads and pendants, a glass bead, and a stone pipe bowl.

\section{M-1894. Engaruka, Sample 151}

$$
200 \pm 100
$$

Charcoal from stone hut Enclosure A.21 on Hillside 1, coll. from central hearth of fireplace near doorway. Maximum internal dimensions of hut, $4 \mathrm{~m}$ by $3 \mathrm{~m}$ surrounded by substantial dry stone wall. Doorway at $\mathrm{N}$ end, and floor paved with large stones at doorway end. Inside doorway, flat stones arranged around small central hearth. Deposit above paring $.15 \mathrm{~cm}$. No cultural remains found.

General Comment (HS): Engoruka dates seem to be settling into period 1400 to 1800 A.D. Late clate, M-1894, fits in with facts. 
Charcoal from Unnam-ri, Yongjong-myon, Puch'on-gun, Kyonggi-do $\left(37^{\circ} 30^{\prime} \mathrm{N}\right.$ Lat, $126^{\circ} 30^{\prime \prime} \mathrm{E}$ Long), W of Seoul at elevation of $127.3 \mathrm{ft}$ on hill overlooking seashore. Wood sample probably young latiloliate tree fast grown under good climatic conditions. Dolmens in Korea are divided into 2 types geographically and stylistically, northern and southern. In excavating this northern-type clolmen, 3 layers of stratification were noticed. Foot of wall stones of dolmen rest in middle of lowest layer. Top layer: dark brownish humus, 8 in. in depth. Middle layer: brownish soil containing tiny pieces of charcoal, 8 in. in clepth. Base: yellowish clay rich in large pieces of charcoal, $161 / 2$ in. in depth. Below layers is schist pan. Charcoal bed must have been laid down as foundation, and is first reported. Northern dolmen is dominant and older type, roughly dated to 3 rd or 4 th c. B.c., which is end of Korean Stone age. No carbon dating has been attempted for Korean dolmens. Coll. 1963 by Sukkyong Choi; subm. by Won-Yong Kim, Seoul Natl. Univ. Comment (WK): dates are at least one millenium younger than expected; thus, impossible. Basal layer from which samples were coll. was not disturbed. Samples must have been contaminated.

\section{REFERENCES}

Date lists:

$\begin{array}{ll}\text { Michigan I } & \text { Crane, 1956 } \\ \text { Michigan III } & \text { Crane and Griffin, 1958 } \\ \text { Michigan V } & \text { Crane and Griffin, 1960 } \\ \text { Michigan VI } & \text { Crane and Griffin, 1961 } \\ \text { Michigan VIII } & \text { Crane and Griffin, 1963 } \\ \text { Michigan X } & \text { Crane and Griffin, 1965 } \\ \text { Michigan XI } & \text { Crane and Griffin, 1966 } \\ \text { Ohio Wesleyan III } & \text { Ogden and Hay, 1967 }\end{array}$

Alexander, R. (. and Reiter, P., 1935, Report on the excavations of Jemez Cave, New Mexico: Monographs of the School of Am. Res., no. 4.

Bell, R. F., 1953, Pottery vessels from the Spiro Mounds: Oklahoma Anthro. Soc. Bull. no. 1 , p. $25-98$.

Benington, F., Melton, C., and Watson, P. J., 1962, Carbon dating prehistoric soot from Salts Cave, Kentucky: Am. Antiquity, v. 28, p. 238-241.

Bluhm, E. and Beeson, W. J., 1960, The excavation of three Hopewell mounds at the Caterpillar Tractor Company: in Indian Mounds and Villages of Illinois, Illinois Archaeol. Sur. Bull., no. 2, p. 1-24.

Brown, J. A., 1966, Spiro studies volume 2, The graves and their contents: Second part of the Second Annual Rep. of Caddoan Archaeol.-Spiro Focus Res.

Brovles, B. J., 1966, Excavations at the St. Albans Archaic site, 1964-1965: Eastern States Archacol. Fed. Bull., no. 25, p. 11.

Camphell. T. E., 1961, Caddoan radiocarbon dates: Bull. Texas Archaeol. Soc. no. 31, p. $145-151$.

Chapman, C. H., 1957, Graham Cave: in a Report of Progress, Archaeological Research by the University of Missouri, 1955-1956.

Clendening, J. A., Renton, J. J., and Parsons, B. M., in press, Preliminary palynological and mineralogical analyses of a Lake Monongahela terrace deposit at Morgantown, West Virginia: West Virginia Ceol. Sur. 
Crane, H. R., 1956, University of Michigan radiocarbon dates I: Sci., v. 124, p. 664-672.

Crane, H. R. and Griffin, J. B., 1958, University of Michigan radiocarbon dates III: Sci., v. 128, no. 3332, p. 1117-1123.

1960, University of Michigan radiocarbon dates V: Amer. Jour. Sci. Radioc. Supp., v. 2, p. 31-48.

1961, The $\mathrm{CO}_{2} \mathrm{CS}_{2}$ Geiger counter: Rev. Sci. Instruments, r. 32, p. 953.

p. $105-125$

1961, University of Michigan radiocarbon dates VI, Radiocarbon, v. 3,

1963, University of Michigan radiocarbon dates VIII: Radiocarbon, r. 5 , p. $298-253$.

1965, Eniversity of Michigan radiocarbon dates $\mathrm{X}$ : Radiocarbon, .7 , p. $123-152$. p. $25(6-285$.

1966, University of Michigan radiocarbon dates XI: Radiocarbon, v. 8,

Cushing, F. H., 1896, Exploration of ancient Key-dweller remains on the Gulf Coast of Florida: Pro. Am. Philosoph. Soc., v. 5.5, no. 153, p. 329-432.

Dellinger, S. (.., 1936, Baby cradles of the Orark Bluff Dwellers: Am. Antiquity, v. 1, no. 3, p. $197-214$.

Fitting, J. E., n.d., The Spring Creck site: Inthropol. Papers, Mus. of Anthopol., Univ. of Michigan, no. 32, in press.

110. 5, p. 738 .

1965, Late Woodland cultures in southeastern Michigan: Anthopol. Papers, Mus. of Anthropol., Univ. of Michigan, no. 24.

Gladwin, H. S. et al., 1937, Excavations at Snaketown: Medallion Papers, v. xxr.

Greenman, E. F., 1927, The earthwork inclosures of Michigan: Ph.1). dissertation, Univ. of Michigan.

Griffin, J. B., 1943, The lort Incient Aspect: Univ. of Michigan Press.

1966, The Calumet ancient pit: Michigan Archaeol., v. 12, no. 3, p. 130-133.

Hall, Robert L., September 1967, Those late corn dates: isotopic fractionation as a source of error in carbon-14 dates: Michigan Archacol., v. 13, no. 3.

Halsey, J. R., n.d., The Springwells Mound Group of Wayne County, Michigan: to be published in Anthropol. Papers, Mus. of Anthropol., Iniv. of Michigan.

Hamilton, H. W., 1952, The Spiro Mound: Missouri Archaeol., v. 14.

Harrington, M. R., 1960. The Ozark Bluff-1)wellers: Mus. of the Am. Indian, Heye Foundation, Indian Notes and Monographs, v. XII.

Harrison, S., 1966, The Schmidt site (20 S.A 192), Saginaw County, Michigan: Michigan Archaeol., v. 12, no. 2, p. 49-70.

Hinsdale, W. B., 1930, Reports of archacological field work in the summer of 1928 in Montmorency, Newaygo and Lake Comties, Michigan: Papers of the Michigan Acal. of Sci., Arts and Letters, v. 12, 1929, p. 127-135.

Hough, J. I.., 1958, Geology of the Great Lakes: Univ. of Illinois Press.

1963, The prehistoric Great Lakes of North America: Am. Scientist, r. 51, 11). 1, p. 84-109.

Hurt, W. B., 1961, Archacological work at the Tabor and Arp sitcs: Mus. News, W.H. Over Mus., State Univ. of South Dakota, v. 22, no. 1.

1963, The 1962 excavations of the Sherman Park mound site, 39 Mn 8 ; a newly radiocarbon dated site in South Dakota: Mus. News, W. H. Over Mus., State Univ. of South Dakota, v. 24, no. 1.

Jones, V. H., 1936, The vegetal remains of Newt Kash Hollow shelter: in Rockshelters in Menifee County, Kentucky, by Webb, W. S. and Funkhouser, W. D.: Univ. of Kentucky Rep. in Archacol. and Anthropol., v. III, no. 4, p. 146-167.

Leakey, L. S. B., 1936, Preliminary report on examination of the Engaruka ruins: Tanganyika Notes and Records, no. 1.

Lietzke, D. A. and Whiteside, E. P., 1967, Comparison of podsol soils in northern Mich. with Nunatak soils in a sub-Arctic maritime climate: Paper presented at annual meeting of the Mich. Acad. Sci., Arts, and Letters, March 1967, Ann Arbor.

Logan, W. D., 1952, Graham Cave, an Archaic site in Montgomery County, Missouri: Missouri Archacol. Soc. Mem. no. 2. 
Mason, R. A., 1966, Two stratified sites on the Door Peninsula of Wisconsin: Anthropol. Papers, Mus. of Anthropol., Univ. of Michigan, no. 26.

McGimsey, C. R., III, 1963, Two open sites and a shelter in Beaver Reservoir: Arkansals irchacol., v. 1V, no. 10, p. 9-11.

Mckern, W. C., 1963, The Clam River focus: Milwauke Pub. Mus., Publ. in Anthropol., no. 9.

Mcllichacl, k. V., 1962, Preliminary report on excavations at the Mrt. Carbon village, 46 F.I 7: West Virginia Archacol., no. 14, p. 36-50.

1963, Niddle Woodland Hopewellian discoveries in the Kanawha Valles, W'est Virginia: Eastom States Archacol. Fed. Bull. 22, p. 13-14.

1966, Three seasons work at the Buffalo site, Punam County, West Virginia: Lastem States Archacol. Fed. Bull. 25, p. $11-12$.

MCPherron, I. L., 1967, The Juntunen site and the Iate Woodland prehistory of the Upper Great Lakes area: Anthropol. Papers, Mus. of Anthropol., Cnis. of
Michigan, no. 30 .

Millon, R. and Bemnyhoff, J., 1961, I long architectural sequence at Teotihuacan: Am. Intipuity, ․ 26, no. 4, p. 516-523.

Miller, M. M., 1966, Progress report on National Geographic Society Maskan Giacier Commemorative project - Summer Phase, 1966.

Miller, M. M., Anderson, J. H., and Egan, C. P.. 1967, Neoglacial climatic chronology from radiocarbon eridence: Paper presented at the ammual mecting of the Michigan Acad. Sci., Arts, and Letters, March 1967, Inn . Mrbor.

Morse, D. F. and Morse, P. A., 1965, The Hannah site, Peoria County, Illinois: in Middle Woodland sites in Illinois, Illinois Archacol. Sur. Bull., no. : p. 129-146.

Nogucra, k., 1943, Exavations en Tepalcate, Chimathuacan, Mexico: Am. Intiquity, v. 9, no. 1, p. $35-43$.

Ogden, J. G., III and Hay, R. J., 1967, Ohio Wesleyan Lnis. natural radiocarbon measurements III: Radiocarbon, v. 9, p. 316-332.

OrT, K. G., 1946, The archacological situation at spiro, Oklahoma: A preliminary report: Im. Intiquily, v. 11, 110. 4, p. 228-255.

1952, Survey of Caddoan area archacology; in Archacol. of Eastem U.S., cl. by Griffin, J. B., p. 239-256. Prahl, E. J., 1966, The Muskegon River sursey: 1965 and 1966: Michigan Archacol.,
v. 12, no. t, p. 183-209.

Price, J. C... Hunter R. (;., and McMichael, E. V., 1964, core drilling in an archacological site: Am. Antiquity, v. 30 , no. 2, p. 219-222.

Prufer, O., 1965, The McGraw site: a study in Hopewellian dynamics: Sci. Pub of the Cleveland Mus. of Nat. Hist., n.s., v. 4, no. 1.

Porras Garcés, P. I., 1961, Contribucion al Fstuclio de la Argucologia e Historia de los Valles Quijos y Misagualli (. Mto Napo) en la Region Oriental del Ecuador, S. 1.: lenix, Quito.

Sassoon, H. 1966, lingarukal a report on excavations carried out in 1964: Azania, v. 1. $196 \overline{7}$, New Views on Engaruka: Jour. of African History, v. VIII, pt. 2. Schwartz, D. W., 1960, Prehistoric man in Mammoth (ave: Sci. Lm., v. 203, no. 1, p. 130-140.

Thomas, R. A., 1962, Projectile point sequence at Breckenridge Shelter: Mrkansas Archacol., v. III, no. 10, p. 1.2 .

Van Nice, R. 1., 1963, The structure of Hagia Sophia: Architectural Forum, r. I18, no. 5, p. 131-138.

Wagner, W. P', 1966, Correlation of Rocky Mountain and Laurentide glacial chronologies in southwestern .llherta, Canada: Univ. of Mich., Univ. Microfilms, Ph.l). dissertation.

Watson, P. J. and Yarnell, R. A., 1966, Archaeological and paleoethnobotanical investigations in Salts Cave, Mammoth Cave National Park, Kentucky: Am. Antiquity, v. 31 , no. 6, p. $842-849$.

Wedel, W. R., 1943, Archacological investigations in platte and clay Counties, Missouri: Smithsonian Inst., U.S. Natl. Bull., no. 183. 
Wittry, W. L., 1965, The Institute digs a mastodon: Cranbrook Inst. of Sci. Newsletter, v. 35, no. 2, p. $14-19$.

Wood, W. R., 1961, The Pomme de Terre Reservoir in western Missouri prehistory: Missouri Archacol., v. 23, p. 52-62, 70-71, 87-118.

1963, Breckenridge shelter - 3CR2: an archaeological chronicle in the Beaver Reservoir area: in Arkansas Archaeol. 1962, ed. by C. R. McGimsey, III, p. $67-96$.

1966, Archacological investigations in the Stockton Reservoir area, western Missouri: the 1965 field season: Report to the Nat'l Park Service, on file at the Univ. of Missouri.

Wood, W. R. and Marshall, R. A., 1958, The Loftin component, 23SN42: Ms. submitted to the Nat'l. Park Service, on file at the Univ. of Missouri.

Wray, D. E. and MacNeish, R. S., 1961, The Hopewellian and Weaver occupation of the Weaver site, Fulton Comnty, Illinois: Illinois State Mus. Sci. Papers, v. 7, no. 2, p. $1-76$. 